\title{
Article \\ Bis(Tryptophan) Amphiphiles Form Ion Conducting Pores and Enhance Antimicrobial Activity against Resistant Bacteria
}

\author{
Mohit Patel ${ }^{1,2}$, Saeedeh Negin ${ }^{1,2}$, Joseph Meisel ${ }^{3}$, Shanheng Yin ${ }^{1,2}$, Michael Gokel ${ }^{1,2}$, Hannah Gill ${ }^{1,2}$ \\ and George Gokel ${ }^{1,2, *}$ \\ 1 Department of Chemistry \& Biochemistry, University of Missouri, St. Louis, MO 63121, USA; \\ mohitpatel87@gmail.com (M.P.); saeedehnegin@gmail.com (S.N.); syx97@mail.umsl.edu (S.Y.); \\ gokel.mike@gmail.com (M.G.); hannahgill122@gmail.com (H.G.) \\ 2 Department of Biology, University of Missouri, St. Louis, MO 63121, USA \\ 3 Department of Chemistry, George Washington University, Washington, DC 20052, USA; \\ jmeisel@gwu.edu \\ * Correspondence: gokelg@umsl.edu; Tel.: +1-(314)-516-5321
}

check for updates

Citation: Patel, M.; Negin, S.; Meisel, J.; Yin, S.; Gokel, M.; Gill, H.; Gokel, G. Bis(Tryptophan) Amphiphiles Form Ion Conducting Pores and Enhance Antimicrobial Activity against Resistant Bacteria. Antibiotics 2021, 10 , 1391. https://doi.org/10.3390/ antibiotics10111391

\section{Academic Editors:}

Daniele Castagnolo, Jürgen Brem, Mark G. Moloney and Sónia Silva

Received: 11 October 2021

Accepted: 8 November 2021

Published: 12 November 2021

Publisher's Note: MDPI stays neutral with regard to jurisdictional claims in published maps and institutional affiliations.

Copyright: (c) 2021 by the authors. Licensee MDPI, Basel, Switzerland. This article is an open access article distributed under the terms and conditions of the Creative Commons Attribution (CC BY) license (https:// creativecommons.org/licenses/by/ $4.0 /)$.

\begin{abstract}
The compounds referred to as bis(tryptophan)s (BTs) have shown activity as antimicrobials. The hypothesis that the activity of these novel amphiphiles results from insertion in bilayer membranes and transport of cations is supported by planar bilayer voltage-clamp studies reported herein. In addition, fluorescence studies of propidium iodide penetration of vital bacteria confirmed enhanced permeability. It was also found that BTs having either meta-phenylene or n-dodecylene linkers function as effective adjuvants to enhance the properties of FDA-approved antimicrobials against organisms such as S. aureus. In one example, a BT-mediated synergistic effect enhanced the potency of norfloxacin against $S$. aureus by 128 -fold. In order to determine if related compounds in which tryptophan was replaced by other common amino acids $\left(\mathrm{H}_{2} \mathrm{~N}\right.$-Aaa-linker-Aaa- $\left.\mathrm{NH}_{2}\right)$ we active, a family of analogs have been prepared, characterized, and tested as controls for both antimicrobial activity and as adjuvants for other antimicrobials against both Gram-negative and Gram-positive bacteria. The most active of the compounds surveyed remain the bis(tryptophan) derivatives.
\end{abstract}

Keywords: adjuvant; amino acids; amphiphile; antimicrobial; bacteria; efflux pump; ion channel; pore formation; resistant bacteria; tryptophan

\section{Introduction}

Numerous reports have appeared warning of the increasing threat of illnesses caused by antibiotic-resistant bacteria [1]. Resistance has developed by at least some organisms to nearly all known antimicrobial agents [2]. It is now generally recognized that new and effective solutions to deal with this crisis are essential [3,4] and overdue [5]. Although a few novel antibiotics such as teixobactin [6] have emerged recently, most new antibiotics are derivatives of existing classes of antimicrobials. The crisis is of such significance that both the World Health Organization (WHO) and the Centers for Disease Control and Prevention (CDC) [1] have issued recent, extensive reports. In 2017, the WHO listed 12 bacterial strains that are the greatest threat to public health [7]. It was asserted in that report that the current rate of antibiotic development is inadequate to address this crisis. Of particular concern are multidrug-resistant (MDR) Gram-negative bacteria and methicillin-resistant Staphylococcus aureus (MRSA), which constitute an urgent threat.

Amphiphilic molecules, both natural and synthetic, are known to manifest antimicrobial properties [8]. Amphiphiles localize in and disrupt cell membranes in bacteria. Natural amphiphiles [9] (often peptides [10]) such as colistin [11] and daptomycin are highly effective at inhibiting bacterial growth. Their use has generally been limited owing to toxicity, but the rise in antibiotic resistance has increased demand for them [12]. Colistin [13,14] has been in clinical use for over 50 years, but resistance to it has recently been reported in the 
U.S. [15-18]. Recent research has focused on using colistin as an adjuvant [19-21]. The rate of resistance development to such antibiotics as tetracycline usually allows a 10-15 year lifetime for a new antibiotic in clinical use [5]. Although amphiphiles generally acquire resistance slowly, they are sometimes associated with renal [22] and cardiac cytotoxicity. Recent research involving colistin emphasizes changes to the hydrophobic tail or alterations in the number of positive charges, but significant success has proved to be elusive. Colistin is also now used in prodrug form as colistin methanesulfonate in an effort to lower its cytotoxicity [23].

Previous studies in our laboratory have produced the families of compounds we call lariat ethers [24-26] and hydraphiles [27]. The lariat ethers were designed originally as crown ethers having attached donor group-containing side arms. These side chains provide a ring-bound cation with apical solvation [28]. The lariat ethers proved to be excellent ion carriers [29]. When the donor groups were eliminated from the side arms, certain alkyl lariats aggregated to form channels that function in phospholipid bilayers [30]. Of course, they may continue to function as carriers as well. The hydraphiles were designed as channels that would be active in bilayer membranes and their function as such has been fully characterized and reported [31]. Both classes of compounds exhibit antimicrobial properties and both classes of compounds function as potency-enhancing adjuvants for common antibacterials to which organisms have become resistant [32,33].

Given our success in developing amphiphiles that exhibited antimicrobial properties, we sought to develop other classes of compounds able to insert in membranes that may exhibit antimicrobial properties. The bis(tryptophan)s (BTs) [34] that are the subject of this report were designed as potential amphiphiles presuming that the amino acid's indoles would function as membrane anchors [35,36]. It is well known that tryptophan occurs in many peptides and proteins, such as gramicidin [37,38] and the KcsA voltage-gated ion channel, [39] only at the membrane boundaries. Our own previous work showed that indoles substituted by alkyl chains at either the $\mathrm{N}$ - or 3-position could form stable liposomes [40]. We therefore prepared a family of compounds in which we expected tryptophan to function as a head group. Our design schematic had the general formula $\mathrm{H}_{2} \mathrm{~N}$-Trp-Y-Trp- $\mathrm{NH}_{2}$, in which $\mathrm{Y}$ was alkyl or aryl. The expectation was that tryptophan's indole would serve as a membrane anchor and the molecule would enhance the permeability of the membrane in which it was resident. We have previously reported that several of the bis(tryptophan) compounds exhibited antimicrobial potency and low cytotoxicity [24].

The bis(tryptophan)s recovered tetracycline activity against a tetA efflux pump expressing tetracycline-resistant Escherichia coli $\left(\right.$ tet $\left.^{\mathrm{R}}\right)$ [34]. Limited structure-activity studies for these tryptophan derivatives revealed that charged ammonium moieties, an appropriate spacer, and the presence of tryptophan as the terminal amino acids were all critical for antimicrobial activity. In one example for which D- and L-isomers were prepared, both proved to be active. In this case, the compound having the D,D-configuration was found to be more active than the otherwise identical L,L-derivative against a strain of E. coli. Several of the bis(tryptophan)s showed greater potency against Staphylococcus aureus (ATCC 29213) than E. coli. We now report additional antimicrobial studies, the membrane activity of several BTs, insight into the mechanism of action of these bis(tryptophan)s, and a group of new bis(amino acid)s.

\section{Results and Discussion}

Two key questions persisted in our study of bis(tryptophan)s. First, our hypothesis was that these amphiphiles insert into bacterial membranes (boundary layers) and both increase permeability and affect such enzymes as efflux pumps. Could evidence be developed to support either or both of these assumptions? Second, was the formation of membraneactive amphiphiles based on amino acid head groups possible with any of the other common amino acids? We attempted to resolve the first question by using the planar bilayer voltage clamp experiment and fluorescence techniques. The second issue was addressed by preparing derivatives of the other common amino acids and determining 
their biological activity, if any. The initial group of tryptophan derivatives that were prepared [34] is shown in Figure 1.

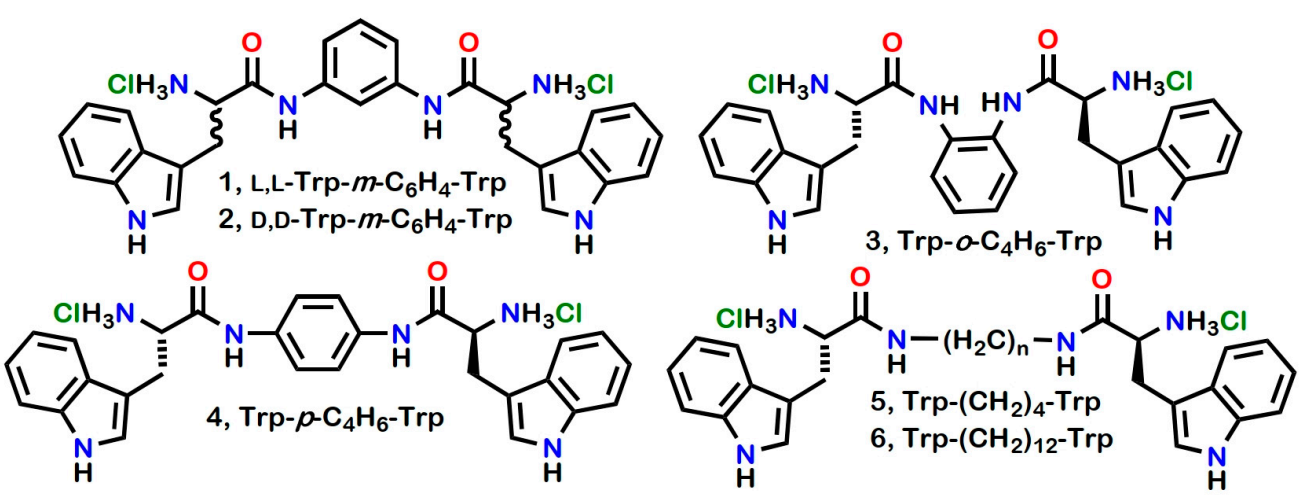

Figure 1. Structures of bis(tryptophan) derivatives 1-6.

\subsection{Channel and Biological Activity}

As noted in the introduction, the tryptophan derivatives were prepared in the expectation that this particular amino acid would serve as a membrane anchor for a membraneactive amphiphile [34]. We recognized that the spacer chain lengths of the compounds prepared would be insufficient for these amphiphiles to span typical bilayer membranes [41]. However, membrane interactions are still possible and a surface-stabilized partial insertion into a membrane is certainly plausible [42]. The planar bilayer voltage clamp (BLM) experiments [43] reported below are useful to detect membrane insertion and especially controlled ion transport.

The BLM experiment was used to assess the membrane behavior of compound $1\left(\mathrm{HCl} \cdot \mathrm{H}_{2} \mathrm{~N}-\mathrm{L}-\mathrm{Trp}-m-\mathrm{C}_{6} \mathrm{H}_{4}-\mathrm{L}-\mathrm{Trp}-\mathrm{NH}_{2} \cdot \mathrm{HCl}, \mathrm{W}-m \mathrm{C}_{6} \mathrm{H}_{4}-\mathrm{W}\right)$. As recorded in Table 1 below, 1 was not the most biologically active structure under study. However, the greatest amount of data had been obtained for it, including comparisons with its structural isomers and stereoisomers. Molecular models suggested that the amino-to-amino span in $\mathbf{1}$ is $\sim 12$ $\AA$. If the tryptophans are in both distal positions of an extended molecule, the overall span could exceed $20 \AA$. Even in that case, this length seems somewhat short to span a bilayer as a single molecule. The hydrocarbon regimes of bilayer membranes are usually estimated at 30-35 ̊, although the insertion of channels may compress the inner and outer membrane leaflets so that the membrane thickness is diminished. Further, the amphiphile may form a barrel stave pore $[42,44,45]$ or a torodial pore $[42,46]$ in which one leaflet of the bilayer reorganizes to pass ions when the pore span is otherwise too short. The membrane behavior of $\mathrm{W}-m \mathrm{C}_{6} \mathrm{H}_{4}-\mathrm{W}(\mathbf{1})$ was investigated in a planar soybean asolectin bilayer membrane.

A BLM study of $\mathrm{W}-\mathrm{m}_{6} \mathrm{H}_{4}-\mathrm{W}(\mathbf{1})$ produced inconsistent results. In contrast, however, the corresponding D,D-isomer (2) showed clear evidence for channel formation. A typical trace is shown in Figure 2. Classical open-close behavior was observed for $\mathbf{2}$ and the ion currents were generally in the expected range of $\sim 30$ picoSiemens. The trace shown indicates that there are two stable open states. This could correspond either to the detection of two open channels or to aggregate formation of undetermined monomer numbers. In either case, the regularity of the trace evinced by 2 is clear. 
Table 1. Minimum Inhibitory Concentrations $(\mu \mathrm{M})$ of Compounds 1-13 and Controls.

\begin{tabular}{|c|c|c|c|}
\hline Cmpd & Spacer (Aaa) & S. aureus 1199B & Tet $^{\mathrm{R}}$ E. coli \\
\hline 1 & meta $-\mathrm{C}_{6} \mathrm{H}_{4}(\mathrm{~L}-\mathrm{Trp})_{2}$ & 128 & 48 \\
\hline 2 & meta- $\mathrm{C}_{6} \mathrm{H}_{4}(\mathrm{D}-\mathrm{Trp})_{2}$ & 16 & 28 \\
\hline 3 & ortho- $\mathrm{C}_{6} \mathrm{H}_{4}(\mathrm{~L}-\mathrm{Trp})_{2}$ & 64 & 56 \\
\hline 4 & para $-\mathrm{C}_{6} \mathrm{H}_{4}(\mathrm{~L}-\mathrm{Trp})_{2}$ & 64 & 120 \\
\hline 5 & $\left(\mathrm{CH}_{2}\right)_{4}(\mathrm{~L}-\mathrm{Tr} \mathrm{p})_{2}$ & 128 & $>128$ \\
\hline 6 & $\left(\mathrm{CH}_{2}\right)_{12}(\mathrm{~L}-\operatorname{Trp})_{2}$ & 4 & 10 \\
\hline 7 & meta- $\mathrm{C}_{6} \mathrm{H}_{4}(\mathrm{~L}-\mathrm{Phe})_{2}$ & $>128$ & $>128$ \\
\hline 8 & meta $-\mathrm{C}_{6} \mathrm{H}_{4}(\mathrm{~L}-\mathrm{Tyr})_{2}$ & $>128$ & $>128$ \\
\hline 9 & meta- $\mathrm{C}_{6} \mathrm{H}_{4}(\mathrm{~L}-\mathrm{Leu})_{2}$ & $>128$ & $>128$ \\
\hline 10 & meta- $\mathrm{C}_{6} \mathrm{H}_{4}(\mathrm{~L}-\mathrm{Ala})_{2}$ & $>128$ & $>128$ \\
\hline 11 & meta- $\mathrm{C}_{6} \mathrm{H}_{4}$ (L-Pro $)_{2}$ & $>128$ & $>128$ \\
\hline 12 & meta $-\mathrm{C}_{6} \mathrm{H}_{4}(\mathrm{~L}-\mathrm{Thr})_{2}$ & $>128$ & $>128$ \\
\hline 13 & meta- $\mathrm{C}_{6} \mathrm{H}_{4}(\mathrm{~L}-\mathrm{Lys})_{2}$ & $>128$ & $>128$ \\
\hline (control) & Tetracycline & $<1$ & $\sim 900$ \\
\hline (control) & Norfloxacin & 64 & $\mathrm{~N} / \mathrm{D}^{\mathrm{b}}$ \\
\hline (control) & Ethidium bromide & 16 & 128 \\
\hline (control) & $\mathrm{CCCP}^{\mathrm{a}}$ & 8 & 64 \\
\hline (control) & Reserpine & $>128$ & $>128$ \\
\hline
\end{tabular}

Notes. ${ }^{\text {a }}$ Carbonyl cyanide $m$-chlorophenyl hydrazine. ${ }^{\mathrm{b}}$ Not determined.

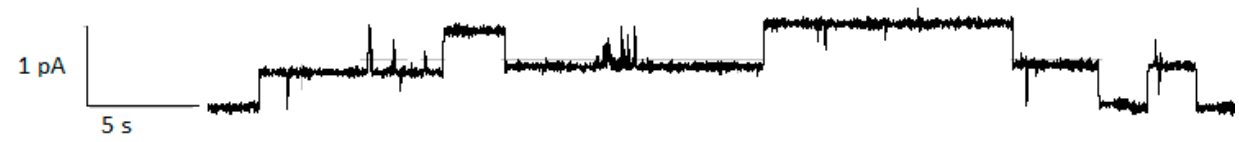

Figure 2. Planar bilayer voltage clamp trace for 2 in asolection bilayers, applied voltage $=30 \mathrm{mV}$, $10 \mathrm{mM}$ HEPES buffer, $[\mathrm{KCl}]=450 \mathrm{mM}$.

Since differences in the two stereogenic centers do not alter overall length, there may be a selective interaction of $\mathbf{2}$ with the chiral element, i.e., the $R$ stereochemistry of the sn-2 center in asolectin's phospholipid monomers. It seems more likely, however, that any difference results from experimental vicissitudes of the complex planar bilayer experiment.

Little membrane activity was anticipated for the ortho-phenylene analog (3) owing to the shorter span of the compound. The estimate of $\mathrm{N} \leftrightarrow \mathrm{N}$ distance for either $\mathbf{1}$ or $\mathbf{2}$ is $\sim 12 \AA$ while it is $\sim 9 \AA$ for 3 . Of course, the overall length of these compounds is less consequential if a barrel stave or toroidal pore forms. Notwithstanding the distance differences, 3 showed the most regular open-close behavior that was observed for the phenylene compounds. A typical trace is shown in Figure 3.

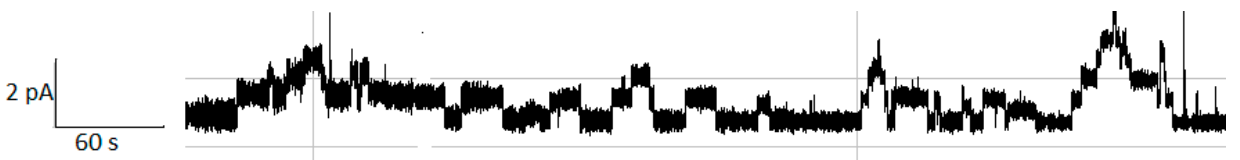

Figure 3. Planar bilayer voltage clamp trace for $\mathrm{W}-o \mathrm{C}_{6} \mathrm{H}_{4}-\mathrm{W}$ (3) in asolectin bilayers, applied voltage $=30 \mathrm{mV}, 10 \mathrm{mM}$ HEPES buffer, $[\mathrm{KCl}]=450 \mathrm{mM}$.

Compound 6, W- $\mathrm{C}_{12}-\mathrm{W}$, was the most biologically active of the bis(tryptophans). A planar bilayer conductance trace is shown in Figure 4. During the experiment, it typically showed some indication of channel activity, but quickly revealed spiking behavior. An attempt was made to obtain planar bilayer results for 1-6, but the traces shown for $\mathbf{2}$ and $\mathbf{3}$ (Figures 2 and 3 ) were the only compounds that afforded reproducible conductance traces. 


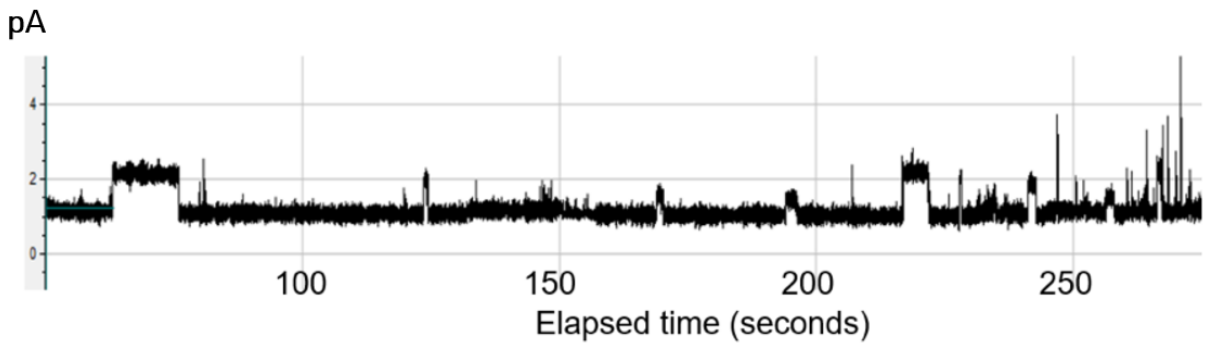

Figure 4. Planar bilayer results for $\mathrm{W}-\mathrm{C}_{12}-\mathrm{W}(6)$. After some initial evidence of conductance, only spiking behavior (right of trace) could be observed.

As was the case with the other diaminophenylene isomers, stable pore formation (BLM traces) was not observed for the para-phenylene BT [W- $p \mathrm{C}_{6} \mathrm{H}_{4}-\mathrm{W}$ (4)]. Of the three phenylenediamine derivatives, the $p$-isomer was the least potent against the bacteria tested. The small difference in span alone does not appear to explain either the low potency or the lack of detectable planar bilayer activity. As above, the latter may be an experimental issue. Perhaps the para-compound is conformationally more rigid than the ortho- or metaisomers. The melting points for the ortho- (3), meta- (1) and para-isomeric (4) BTs are $201^{\circ} \mathrm{C}$, $154-156{ }^{\circ} \mathrm{C}$, and $237^{\circ} \mathrm{C}$, respectively, suggesting a stronger crystal matrix that comports with lower solubility of the para-isomer.

The conductances observed for compounds $\mathbf{2}$ and $\mathbf{3}$, which formed stable pores were appropriate $(\sim 30 \mathrm{pS})$ for transport of $\mathrm{K}^{+}$. It is currently unknown if the active compounds function as monomers or as aggregates. If aggregation does occur, it seems most likely with $\mathrm{W}-o \mathrm{C}_{6} \mathrm{H}_{4}-\mathrm{W}(3)$, which is the shortest of the BTs. Aggregation may also occur with 2 and 6 , each of which shows more than one conductance state, possibly indicating pore formation by $\boldsymbol{2}_{\mathrm{n}}$ and $\boldsymbol{6}_{\mathrm{n}}$ assemblies [30].

\subsection{Membrane Permeability}

The formation of pores could significantly affect the amount of an exogenous compound that penetrates the target organism. The presence of pores should reorganize (disorganize) or disrupt the adjacent phospholipids and increase the membrane's permeability [42]. Of course, membrane disrupting compounds that fail to form organized pore assemblies could also enhance membrane leakage. A bacterial permeability analysis was conducted that comprised a fluorescent assay of the three most bioactive BTs. S. aureus was exposed to propidium iodide over a range of concentrations in the presence or absence of BTs. Propidium iodide normally fails to penetrate bilayer or bacterial boundary membranes. The fluorescence arising from penetration of the cells was evaluated quantitatively to establish which $\mathrm{BT}$ engendered the greatest membrane permeability.

Compounds $1\left(\mathrm{~W}-m \mathrm{C}_{6} \mathrm{H}_{4}-\mathrm{W}\right), 2\left(\mathrm{w}-m \mathrm{C}_{6} \mathrm{H}_{4}-\mathrm{w}\right)$ and $\mathbf{6}\left(\mathrm{W}-n \mathrm{C}_{12}-\mathrm{W}\right)$ were chosen for study. The data in Table 2 (presented later in this report) showed that $\mathrm{W}-n \mathrm{C}_{12}-\mathrm{W}$ (6) was the most bioactive compound in the group surveyed, followed by w- $m \mathrm{C}_{6} \mathrm{H}_{4}-\mathrm{w}(2)$ and $\mathrm{W}-$ $m \mathrm{C}_{6} \mathrm{H}_{4}-\mathrm{W}$ (1). Both the D,D- and L, L-isomers (1 and 2) were studied as their antimicrobial potencies differed. S. aureus was the organism used in the study. In each case, it was exposed to propidium iodide (see Figure 5) in the presence of the indicated concentration of BT or control. Propidium iodide does not normally penetrate vital cells. When it does enter cells, it intercalates into DNA and a fluorescent signal is detected. The intensity of the fluorescence is proportional to the penetration of the salt. Controls in the study shown in Figure 6 included S. aureus alone, in the presence of $0.5 \% \mathrm{DMSO}$, and either $0.1 \%$ or $0.01 \%$ of Triton X-100 (abbreviated TX100) detergent. The percentages of Triton X-100 expressed as concentration correspond to $170 \mu \mathrm{M}$ and $17 \mu \mathrm{M}$, respectively. The DMSO control is important to show that the cosolvent used has no effect on the system. Triton $\mathrm{X}-100$ was used to demonstrate that a simple detergent at low concentration does not enhance permeability. 
Table 2. MICs $(\mu \mathrm{M})$ of $\mathrm{W}-n \mathrm{C}_{12}-\mathrm{W}$ and antibiotics.

\begin{tabular}{|c|c|c|c|c|}
\hline \multirow{2}{*}{ Organism } & \multirow{2}{*}{ Phenotype } & \multicolumn{2}{|c|}{ Controls } & \multirow{2}{*}{$\mathrm{W}-n \mathrm{C}_{12}-\mathrm{W}$} \\
\hline & & Vancomycin & Meropenem & \\
\hline S. aureus & CLSI control $^{\mathrm{a}}$ & 0.3 & - & 9 \\
\hline MRSA & USA $100^{\mathrm{b}}$ & 0.7 & - & 9 \\
\hline MRSA & USA $300^{c}$ & 0.3 & - & 9 \\
\hline E. faecalis & CLSI control $^{\mathrm{a}}$ & 1.4 & - & 18 \\
\hline E. faecium & $\operatorname{Van} A^{d}$ & 22 & - & 9 \\
\hline E.faecalis & $\operatorname{VanB}^{\mathrm{e}}$ & $>44$ & - & 18 \\
\hline S. pneumoniae & CLSI control $^{\text {a }}$ & 0.2 & - & 9 \\
\hline S. pneumoniae & R: Pen ${ }^{f}$ & 0.2 & - & 9 \\
\hline S. pneumoniae & R: Levo $\mathrm{g}$ & 0.2 & - & 9 \\
\hline K. pneumoniae & $\mathrm{KPC}-3^{\mathrm{h}}$ & - & $>167$ & $>18$ \\
\hline K. pneumoniae & KPC- $3^{h}$ & - & 83 & $>18$ \\
\hline K. pneumoniae & VIM $^{\mathrm{i}}$ & - & 10 & $>18$ \\
\hline P. aeruginosa & CLSI control $^{a}$ & - & 1.3 & $>18$ \\
\hline P. aeruginosa & UNC-D ${ }^{j}$ & - & 21 & $>18$ \\
\hline P. aeruginosa & VIM $^{\mathrm{k}}$ & - & $>167$ & $>18$ \\
\hline E. coli & MN VA Med center ${ }^{1}$ & - & $\leq 0.3$ & $>18$ \\
\hline E. coli & MN VA Med center ${ }^{1}$ & - & $\leq 0.3$ & $>18$ \\
\hline E. coli & MI VA Med $^{\mathrm{m}}$ & - & $\leq 0.3$ & $>18$ \\
\hline
\end{tabular}

Notes. ${ }^{a}$ Clinical Laboratory Standards Institute. ${ }^{\mathrm{b}}$ Methicillin-resistant Staphylococcus aureus strain: USA 100. ${ }^{\mathrm{c}}$ Methicillin-resistant S. aureus strain: USA 300. ${ }^{\mathrm{d}}$ Vancomycin-resistant Enterococcus faecium A. ${ }^{\mathrm{e}}$ Vancomycinresistant Enterococcus faecalis B. ${ }^{\mathrm{f}}$ Penicillin-resistant Streptococcus pneumoniae. ${ }^{\mathrm{g}}$ Levofloxacin-resistant Streptococcus pneumoniae. ${ }^{\mathrm{h}}$ Carbapenem-resistant Klebsiella pneumoniae. ${ }^{\mathrm{i}}$ Metallo- $\beta$-lactamase-producing. ${ }^{\mathrm{j}}$ Resistant to ceftazidime, meropenem, imipenem, and tobramycin. ${ }^{k}$ Carbapenem-hydrolyzing enzymes, metallo- $\beta$-lactamaseproducing microbe. ${ }^{1}$ Isolate from patient urine at Minneapolis Veterans Administration Hospital. ${ }^{\mathrm{m}}$ Isolate from a patient at the Detroit Veterans Administration Hospital.

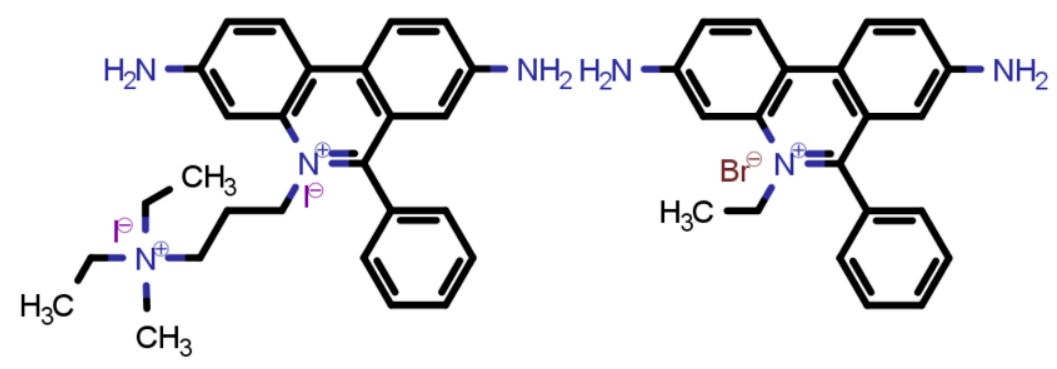

Figure 5. Structures of propidium iodide (left) and ethidium bromide (right), non-membrane permeable, fluorescent agents that stain by DNA intercalation.

The concentration range studied for added BTs was $500 \mathrm{nM}$ to $32 \mu \mathrm{M}$. The system was indifferent to the presence of $0.5 \%$ DMSO. Some increase in membrane permeability is apparent with Triton X-100 controls having concentrations up to $170 \mu \mathrm{M}$. The BTs showed no significant increase in fluorescence and thus propidium iodide penetration below $2 \mu \mathrm{M}$. However, from $4 \mu \mathrm{M}$ to $32 \mu \mathrm{M}, 6\left(\mathrm{~W}-n \mathrm{C}_{12}-\mathrm{W}\right)$ mediated propidium iodide fluorescence (cell penetration) by approximately threefold. While little change in fluorescence was observed for $\mathbf{1}\left(\mathrm{W}-m \mathrm{C}_{6} \mathrm{H}_{4}-\mathrm{W}\right)$, isomer $2\left(\mathrm{w}-m \mathrm{C}_{6} \mathrm{H}_{4}-\mathrm{w}\right)$ fostered an increase in fluorescence to approximately 1.8 -fold at $32 \mu \mathrm{M}$.

The MICs (Tables 2 and 3) of $\mathrm{W}-n \mathrm{C}_{12}-\mathrm{W}(6)$ against $S$. aureus and E. coli were $4 \mu \mathrm{M}$ and $10 \mu \mathrm{M}$, respectively. The D,D- (2) and L, L-forms (1) of $\mathrm{W}-m \mathrm{C}_{6} \mathrm{H}_{4}-\mathrm{W}$ were both active, but showed different biological potencies. Against $S$. aureus, the D,D-compound's MIC was $16 \mu \mathrm{M}$ compared to $128 \mu \mathrm{M}$ for the L,L-form. Likewise, the D,D-compound's MIC against E. coli was $28 \mu \mathrm{M}$ compared to $48 \mu \mathrm{M}$ for the $\mathrm{L}$, L-isomer. 


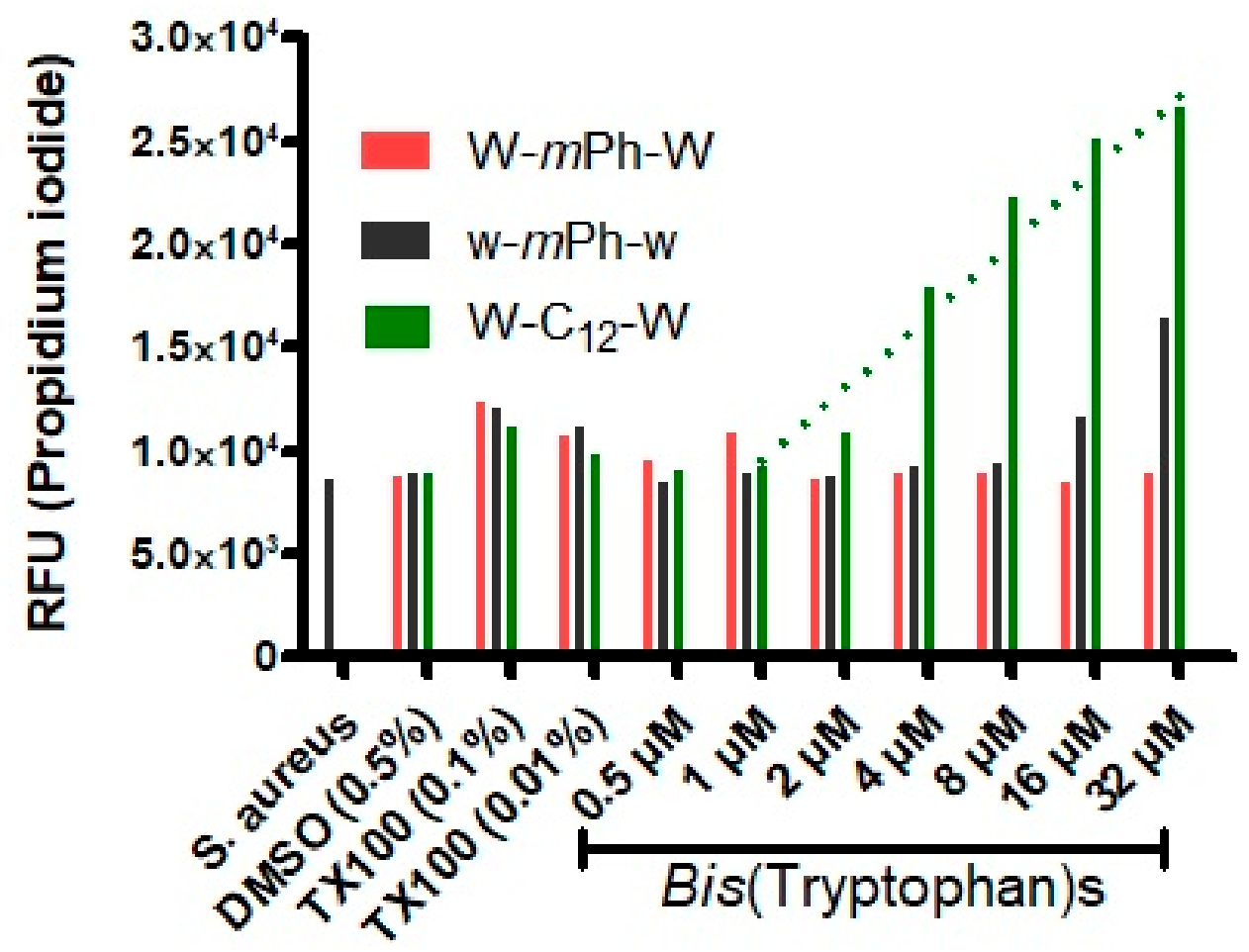

Figure 6. Fluorescence-based assay for propidium iodide penetration of $S$. aureus cells. RFU = relative fluorescence units. TX100 $=$ Triton X-100. $\mathrm{W}=$ L-tryptophan; $\mathrm{w}=\mathrm{D}$-tryptophan. Each bar represents three independent determinations; error bars removed for clarity. The compound numbers corresponding to the structures are $\mathrm{W}-m \mathrm{Ph}-\mathrm{W}, \mathbf{1} ; \mathrm{w}-m \mathrm{Ph}-\mathrm{w}, \mathbf{2}$; and $\mathrm{W}-\mathrm{C}_{12}-\mathrm{W}, 6$.

Table 3. Quantitative summary of Figure 7 S. aureus results.

\begin{tabular}{|c|c|c|c|c|c|c|}
\hline Example $^{a}$ & X-Axis & $\operatorname{MIC~X(\mu M)}$ & Y-Axis & $\operatorname{MIC~Y~}(\mu \mathrm{M})$ & Enhancement $^{b}$ & FIC Index ${ }^{c}$ \\
\hline A & Norfloxacin & 0.5 & $\mathrm{~W}-n \mathrm{C}_{12}-\mathrm{W}(\mathbf{6})$ & 2 & 128 & 0.51 \\
\hline B & Norfloxacin & 0.5 & $\mathrm{w}-m \mathrm{C}_{6} \mathrm{H}_{4}-\mathrm{w}(2)$ & 8 & 128 & 0.51 \\
\hline $\mathrm{C}$ & Norfloxacin & 4 & $\mathrm{~W}-m \mathrm{C}_{6} \mathrm{H}_{4}-\mathrm{W}(\mathbf{1})$ & 32 & 16 & 0.31 \\
\hline $\mathbf{D}$ & Ethidium Br & 2 & $\mathrm{~W}-n \mathrm{C}_{12}-\mathrm{W}(\mathbf{6})$ & 1 & 8 & 0.37 \\
\hline $\mathbf{E}$ & Ethidium Br & 4 & $\mathrm{w}-m \mathrm{C}_{6} \mathrm{H}_{4}-\mathrm{w}(2)$ & 4 & 4 & 0.5 \\
\hline $\mathbf{F}$ & Ethidium Br & 1 & $\mathrm{~W}-m \mathrm{C}_{6} \mathrm{H}_{4}-\mathrm{W}(\mathbf{1})$ & 32 & 16 & 0.31 \\
\hline G & Norfloxacin & 0.5 & $\mathrm{CCCP}^{\mathrm{d}}$ & 4 & 128 & 0.51 \\
\hline $\mathbf{H}$ & Ethidium Br & 0.25 & $\mathrm{CCCP}^{\mathrm{d}}$ & 4 & 128 & 0.510 \\
\hline
\end{tabular}

Notes. a See Figure 7. b Increase in potency in combination with the " $Y$-axis" compound. $c$ FIC Index $=$ ([Adjuvant $\left.]_{\text {COMBINATION }} /[\text { MIC }]_{\text {ADJUVANT ALONE }}\right)+\left(\{\text { Antibiotic }]_{\text {COMBINATION }} /[\text { MIC }]_{\text {ANTIBIOTIC ALONE }}\right) .{ }^{d}$ CCCP $=$ Carbonyl cyanide $m$ chlorophenyl hydrazone.

The results of the membrane permeability study correlate well with the MIC of $\mathrm{W}-\mathrm{C}_{12^{-}}$ $\mathrm{W}$ (6) i.e., $4 \mu \mathrm{M}$. The first significant permeability enhancement over controls is observed at the same concentration. Successive doubling of the concentration affords a nearly linear increase in permeability as gauged by propidium iodide penetration. [Actually an exponential curve $\left(\mathrm{R}^{2}=0.998\right)$ owing to the doubling of MICs (data not shown).] A similar profile is observed for D,D-Trp- $m \mathrm{C}_{6} \mathrm{H}_{4}$-Trp (2). The L,L-isomer showed little activity over this concentration range. 

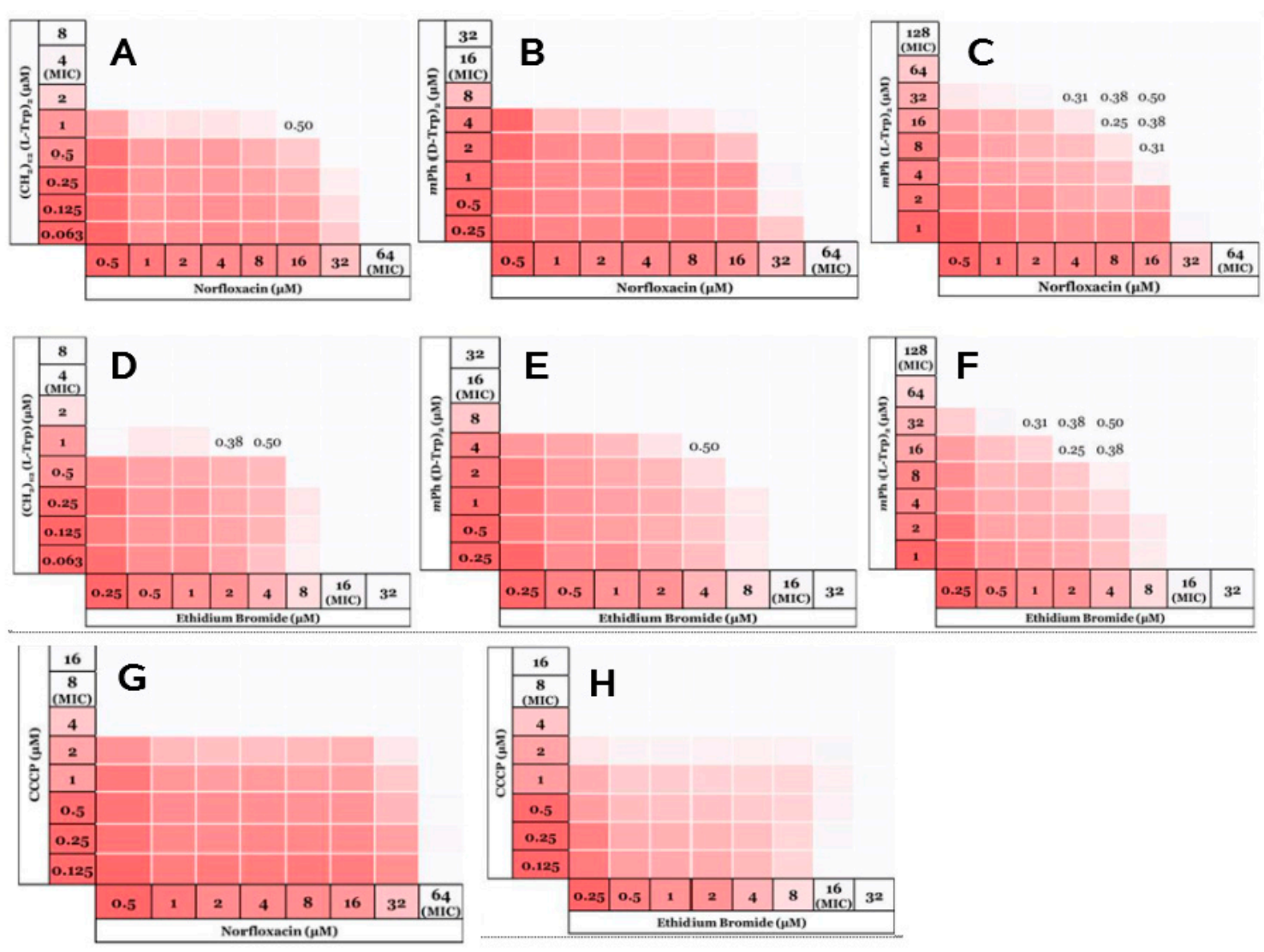

Figure 7. Checkerboard analysis of cooperative function of two different compounds assessed against S. aureus. The $y$-axis and $x$-axis compound concentrations $(\mu \mathrm{M})$ respectively are identified for checkerboards $\mathrm{A}-\mathrm{H}$ as follows. (A) W-C $12-\mathrm{W}(6)$, norfloxacin; (B) $\mathrm{w}-m \mathrm{C}_{6} \mathrm{H}_{4}-\mathrm{w}$ (2), norfloxacin; (C) $\mathrm{W}-m \mathrm{C}_{6} \mathrm{H}_{4}-\mathrm{W}$, norfloxacin; (D) $\mathrm{W}-n \mathrm{C}_{12}-\mathrm{W}$ (6), ethidium bromide; (E) $\mathrm{w}$ $m \mathrm{C}_{6} \mathrm{H}_{4}$-w, ethidium bromide; (F) W- $m \mathrm{C}_{6} \mathrm{H}_{4}-\mathrm{W}$ (1), ethidium bromide; (G) CCCP, norfloxacin; (H) CCCP, ethidium bromide.

A surprising observation arising from the propidium iodide experiment concerns the difference in propidium iodide penetration of $S$. aureus in the presence of $W-m \mathrm{C}_{6} \mathrm{H}_{4}-\mathrm{W}$ (1) and its isomer, $\mathrm{w}-m \mathrm{C}_{6} \mathrm{H}_{4}-\mathrm{w}$ (2). The latter was prepared as a test for metabolic stability. It was surmised that D-Trp linkages would be metabolized less readily than L-Trp by endogenous amidases and therefore be more persistent within the organism. There was no expectation that differences in stereochemistry would affect propidium iodide penetration through S. aureus membranes. The only stereogenic element in typical phospholipid bilayer membranes occurs at the sn-2 carbon of glycerol. Bittman, Koeppe, and coworkers showed that the channel-forming peptide gramicidin's conductance did not depend on the phospholipid stereochemistry [47]. Further, the glyceryl regime of bilayers is not in contact with bulk water, but is in an environment estimated to have a dielectric constant near 25 [48]. Of course, the boundary layer/membrane in Gram-positive S. aureus is more complex than a simple bilayer. Even so, the difference in permeability behavior between these two compounds is intriguing although not currently understood.

\subsection{Checkerboard Experiments}

In previous studies with synthetic amphiphiles, we found that synergy with FDAapproved drugs was possible. Several candidates were available among compounds 1-6, but combination experiments were conducted only with $\mathrm{W}-m \mathrm{C}_{6} \mathrm{H}_{4}-\mathrm{W}(\mathbf{1}), \mathrm{w}-m \mathrm{C}_{6} \mathrm{H}_{4}-\mathrm{w}$ (2) and $W-n C_{12}-W(6)$, owing to their superior potencies. Studies were conducted with the three BTs and with an efflux pump inhibitor control [carbonyl cyanide $m$-chlorophenyl hydrazine (CCCP)] in the presence of either norfloxacin or ethidium bromide. CCCP was used as a positive control. The target organism was $S$. aureus expressing a norA efflux pump. This efflux pump provides resistance to norfloxacin and ethidium bromide by actively 
pumping them out. Efflux pump function is dependent on a cation gradient. Non-rectifying channel activity should lead to disruption of ion gradients on which efflux pumps depend. Pore formation should affect ion gradients, which in turn will reduce pump function. This, in combination with membrane disruption, should allow for greater accumulation of substrate, here norfloxacin and ethidium bromide, in the bacterial cytoplasm. Enhanced antimicrobial efficacy or recovery of potency should be observed regardless of resistance mechanism. This hypothesis was tested by conducting the checkerboard experiments shown below.

The target organism was S. aureus 1199B. The data are presented in Figure 7 in the checkerboard format. The $y$-axis in each graph shows the concentration of BT or CCCP. In panels $\mathrm{A}, \mathrm{B}$, and $\mathrm{C}$, the $x$-axis shows [norfloxacin]. In panels $\mathrm{D}, \mathrm{E}$, and $\mathrm{F}$, the $x$-axis shows [ethidium bromide] (EthBr). Panels G and H parallel A-C and F, respectively, except that $[C C C P]$ is shown on the $y$-axis. The intensity of the red color indicates the growth of viable bacteria. The darker the hue the greater the cell viability. The MIC concentrations of the compounds used in each experiment are marked. The growth/viability of $S$. aureus in the presence of the BT, norfloxacin, or ethidium bromide alone is also indicated by the shade of red. Ethidium bromide is not an antibiotic, but it is used here to screen the efficacy of efflux pumps as it is one of their substrates. Thus, the comparison of A-C and G show the combination potency of either a BT or CCCP. Panels D-F and H show the penetration of EthBr into cells. The experimental results shown in Figure 7 are summarized in Table 3.

Each colored square represents the growth of bacteria in the presence of two compounds. Bacterial growth inhibition of greater than $95 \%$ is shown as white. For example, in Figure 7A, in the presence of half-MIC of $2 \mu \mathrm{M}$ of $\mathrm{W}-n \mathrm{C}_{12}-\mathrm{W}(6)$ and $0.5 \mu \mathrm{M}$ norfloxacin, S. aureus growth was inhibited by $>95 \%$. A clear solution indicating no or very low growth of bacteria is also observed in the presence of $2 \mu \mathrm{M}$ of compound 6 alone and $0.5 \mu \mathrm{M}$ norfloxacin alone. At $\frac{1}{2}$ MIC of $\mathrm{W}-n \mathrm{C}_{12}-\mathrm{W}$ (6) (Figure 7A,D), complete recovery of norfloxacin and ethidium bromide potency was observed. Similar activities were observed with other compounds at $\frac{1}{2}$ MIC (Figure 7B,C,E,F). The activity of the antibiotic was recovered regardless of resistance from efflux pumps in S. aureus. Several examples of such results are shown in Table 2.

Further analysis of combination activity was conducted by calculating the FIC Index (F-index) [49,50]. The F-index is defined as the (active concentration of BT/MIC of BT) + (active concentration of antibiotic/MIC of antibiotic). An F-index of $<0.5$ is considered to characterize synergistic activity. We observed synergistic activity with $\mathrm{W}-m \mathrm{C}_{6} \mathrm{H}_{4}-\mathrm{W}$ (1) compounds (Figure $7 \mathrm{C}, \mathrm{F}$ ) at [norfloxacin] as low as $2 \mu \mathrm{M}$ (F-index $=0.31$ ). W- $n \mathrm{C}_{12}-\mathrm{W}(\mathbf{6})$ also showed synergy, but only with ethidium bromide, which is not used as an antibiotic. Overall, the three tryptophan compounds tested recovered antibiotic potency in resistant S. aureus. Of the three, $\mathrm{W}-m \mathrm{C}_{6} \mathrm{H}_{4}-\mathrm{W}(\mathbf{1})$ showed the most promising combination activity despite its lower activity than 2 or 6 .

It is interesting to note that the relationship between membrane activity and antimicrobial potency for the BTs. The definition for synergy, the F-index of $<0.5$, is somewhat arbitrary. However, a comparison of the meta-phenylene (1) and dodecylene (6) BTs, suggests that the former are membrane-active and effective ion transporters while the latter are membrane-active, but poor ion transporters (see Figures 2 and 3 vs. Figure 4). The adjuvant studies of $\mathrm{W}-n \mathrm{C}_{12}-\mathrm{W}(\mathbf{6})$ show additivity (F-index $=0.51$ ), but not synergy with norfloxacin. In contrast, the F-index for meta-phenylene derivatives do show F-indices $<0.5$. Our choice of meta-phenylene compounds $(\mathbf{1}, \mathbf{2})$ show synergy and ion transport ability, whereas the dodecylene compound (6) may be primarily a membrane disruptor. We therefore studied the meta-phenylene spacer in order to consider the ion transport and synergy functions.

\subsection{Amino Acid Derivatives}

Several of the previously prepared $\mathrm{H}_{2} \mathrm{~N}$-Trp-Y-Trp- $\mathrm{NH}_{2}$ derivatives showed antimicrobial activity [34]. The most active compound against $E$. coli was $\mathrm{W}-n \mathrm{C}_{12}-\mathrm{W}$ (6). An obvious choice was therefore to prepare the range of amino acid derivatives as $\mathrm{H}_{2} \mathrm{~N}$-AAA- 
$n \mathrm{C}_{12}$-AAA- $\mathrm{NH}_{2}$ compounds. Three considerations directed us to choose $\mathrm{W}-m \mathrm{C}_{6} \mathrm{H}_{4}-\mathrm{W}$ (1) as the model for our first pass analysis instead. First, isolation of $\mathrm{W}-n \mathrm{C}_{12}-\mathrm{W}(\mathbf{6})$ had proved to be more difficult than for the arene derivatives, perhaps owing to the flexible spacer chain. Second, both ease of isolation for the meta-phenylene derivative and the ability to compare it to its structural isomers if activity was observed, favored $\mathrm{W}-m \mathrm{C}_{6} \mathrm{H}_{4}-\mathrm{W}$ (1) as the spacer element. Third, the surprising difference in activity between the D,D- and L,L-isomers (1 and $\mathbf{2}$ ) would present an opportunity for further study if any other amino acid derivative proved to be active.

Thus, the compounds shown in Figure 8 were synthesized. All derivatives of metaphenylenediamine. The terminal amino acids in each case have the L-stereochemistry and are alanine (10), leucine (9), lysine (13), phenylalanine (7), proline (11), threonine (12), tryptophan (1), and tyrosine (8). As noted above, the bis(tryptophan) derivative was previously prepared. The alanine (10) and leucine (9) derivatives were prepared to assess the influence of simple alkyl groups. Threonine and tyrosine possess hydroxyl groups having different $\mathrm{pK}_{\mathrm{A}}$ values, but both can donate and accept hydrogen bonds. Tyrosine, as phenylalanine and tryptophan, is an electron-rich aromatic. The lysine derivative (13) doubles the number of positive charges. It was felt that this group of compounds represented a reasonable range of amino acid variations.

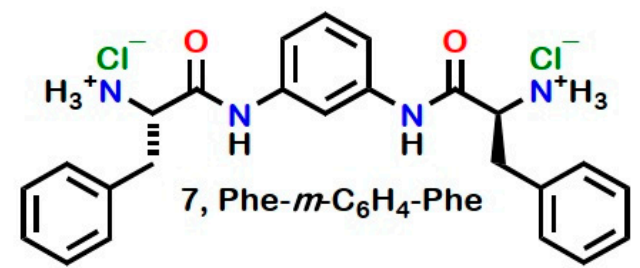<smiles>CC(C)C[C@H]([NH3+])C(=O)Nc1cccc(NC(=O)[C@@H]([NH3+])CC(C)C)c1</smiles>

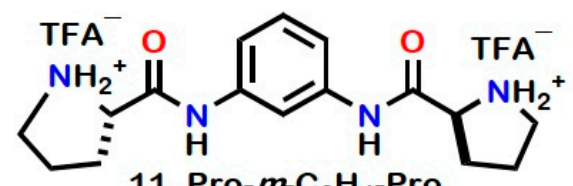
11, Pro- $m-\mathrm{C}_{6} \mathrm{H}_{4}-$ Pro<smiles>[N-][C@@H](Cc1ccc(O)cc1)C(=O)Nc1cccc(NC(=O)[C@H]([NH3+])Cc2ccc(O)cc2)c1</smiles><smiles>C[C@H]([N-])C(=O)Nc1cccc(NC(=O)[C@H](C)[NH3+])c1</smiles>

10, Ala- $m-\mathrm{C}_{6} \mathrm{H}_{4}$-Ala

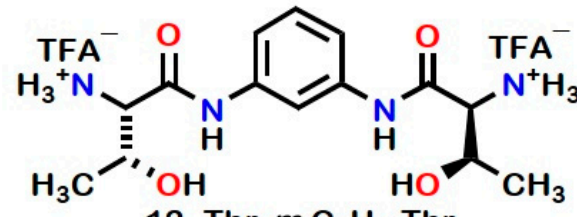

12, Thr- $m-\mathrm{C}_{6} \mathrm{H}_{4}-\mathrm{Thr}$

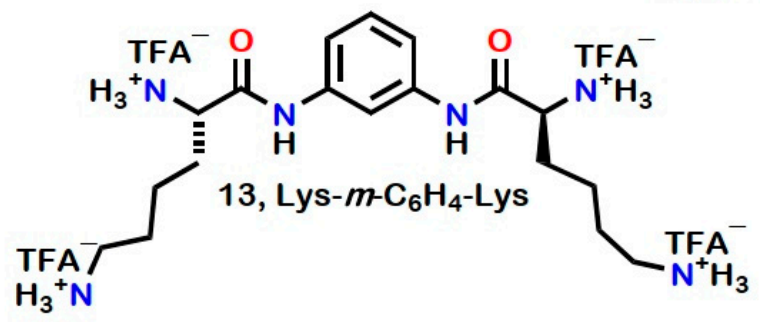

Figure 8. Bis(amino acid) compounds were prepared and used for the present study. All of the new bis(amino acid) compounds or their salts were obtained as colorless solids. They were fully characterized by spectral methods that were found to be in agreement with their assigned structures.

\subsection{Synthesis and Characterization}

The $t$-butyl carbamate-protected (Boc-protected) amino acids were coupled using (2-(1H-benzotriazol-1-yl)-1,1,3,3-tetramethyluronium hexafluorophosphate (HBTU) in DMF with diisopropylethylamine. After workup and isolation of the desired Boc-protected bis(amino)diamide product, deprotection was carried out using acid $(\mathrm{HCl}$ or trifluoroacetic 
acid) in $\mathrm{CH}_{2} \mathrm{Cl}_{2}$. Certain amino acid side chains required additional protecting groups. Their deprotection reactions are noted below and details may be found in the experimental section.

The side chain hydroxyl group of the bis(threonine) compound was protected as the benzyl ether, which was removed by catalytic hydrogenation prior to removal of the Boc group with trifluoracetic acid. The carbobenzyloxy (Cbz) group protected the bis(lysine) compound's side-chain amines. The $\mathrm{Cbz}$ group was removed by catalytic hydrogenation prior to removal of the Boc group by treatment with trifluoroacetic acid to give the tetrakis(trifluoroacetate) salt. The overall synthetic approach is illustrated in Scheme 1. Details of protection/deprotection sequences may be found in the experimental section.<smiles>[R]C(C(=O)O[CH2+])N(CC[C@H](C)Br)NC(=O)OC(C)(C)C</smiles><smiles>[R]C(NC(=O)OC(C)(C)C)[C@@H]([R])NC(=O)Nc1cccc(NC(=O)OC(C)(C)C)c1</smiles>

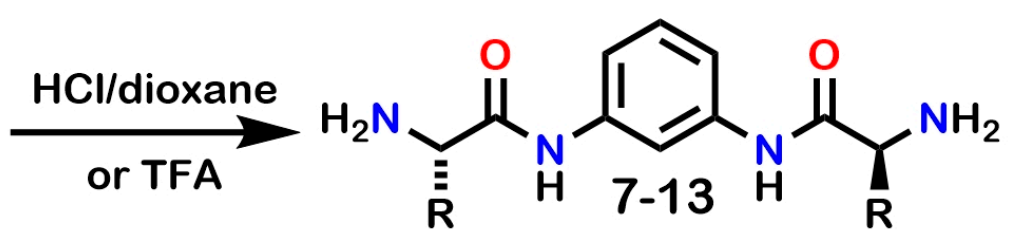

Scheme 1. Synthetic approach to compounds 7-13.

\subsection{Bacterial Strains Used}

Two strains of bacteria were used for the studies reported here: Gram-negative E. coli and Gram-positive S. aureus. The strain of E. coli used was both tetracycline and ampicillinresistant [34]. It was obtained by transforming competent JM-109 cells with the pBR322 plasmid. We have designated this strain as tet ${ }^{R} E$. coli. Tetracycline resistance in this strain results from the expression of the TetA efflux pump. We have previously reported the antimicrobial potencies of several bis(tryptophan)s against tet ${ }^{R}$ E. coli. S. aureus $1199 \mathrm{~B}$ is a clinically relevant strain that overexpresses the NorA efflux pump, but still shows a low level of resistance to norfloxacin. Combination studies with bis(amino acid)s and antibiotics were performed against both tet ${ }^{\mathrm{R}}$ E. coli and S. aureus 1199B.

\subsection{Antimicrobial Activity}

We determined the minimum inhibitory concentrations (MICs) [51,52] of BTs against S. aureus 1199B. In previous work, [24] we studied S. aureus (ATCC 29213). Only the compounds that showed activity in our previous $S$. aureus screen were used for the study here. The data shown in Table 1, comport with values obtained for S. aureus 29213. The results for tet ${ }^{R}$ E. coli that are included in the table were identical to those obtained and published previously [34]. Compounds $\mathbf{2}$ and $\mathbf{6}$ showed the greatest activity. The most active compound had an alkyl spacer $\left(\mathrm{W}-n \mathrm{C}_{12}-\mathrm{W}, 6\right)$ and had MIC values of $4 \mu \mathrm{M}$ and $10 \mu \mathrm{M}$ against $S$. aureus $1199 \mathrm{~B}$ and tet ${ }^{\mathrm{R}}$ E. coli, respectively. Among the bis(tryptophan) compounds, ortho- (3), meta- $(\mathbf{1}, \mathbf{2})$ and para-phenylene (4) spacers, the D,D-meta (2) compound was most active against both organisms. The MIC of 2 was $16 \mu \mathrm{M}$ against S. aureus $1199 \mathrm{~B}$ and $28 \mu \mathrm{M}$ against tet ${ }^{\mathrm{R}}$ E. coli. 
In preparing new structures $\mathbf{7 - 1 3}$, the goal was to determine whether amino acids having side chain residues aside from the indole in tryptophan, the initial inspiration, would lead to antimicrobials. Alanine and leucine are hydrophobic amino acids and not expected to function as headgroups. Threonine and tyrosine have hydroxyl groups that are both polar and capable of hydrogen bonding. These polar elements could function as head groups. Tyrosine and phenylalanine are both electron-rich aromatics and could serve as head groups by dint of forming cation-pi interactions at membrane surfaces [53,54]. Proline is the only cyclic amino acid among the common 20 and no hypothesis was advanced about its amphiphilic behavior. Ultimately, none of 7-13 proved to exhibit antimicrobial properties.

\subsection{In-Depth MIC Screen}

Given that the most active compound in the BT family thus far studied incorporated the dodecylene spacer (i.e., $\mathrm{W}-n \mathrm{C}_{12}-\mathrm{W}, 6$ ), we surveyed its activity more broadly than the two earlier examples: E. coli and S. aureus. The results of that survey are included in Table 3, above. In several cases, the potency study was arbitrarily limited to $18 \mu \mathrm{M}$ (indicated as '>18' $\mu \mathrm{M})$.

Overall, the in-depth analysis showed that compound $6\left(\mathrm{~W}-n \mathrm{C}_{12}-\mathrm{W}\right)$ is more active towards Gram-positive than Gram-negative bacteria. The antimicrobial activity of $\mathbf{6}$ was, in most cases, inferior to that of commercial antibiotics. However, good activity $(<10 \mu \mathrm{M})$ was observed for most of the Gram-positive bacteria such as MRSA, E. faecium, and S. pneumoniae. S. pneumoniae is a major cause of community-acquired pneumonia and MRSA is involved in various skin and soft tissue infections, hospital-acquired pneumonia, ventilator-associated pneumonia, etc.

Where vancomycin was tested against the indicated microbe, it was generally superior to the BTs. However, two cases show that the BTs are more potent and potentially applicable where drug resistance has developed. Vancomycin-resistant Enterococcus faecalis and Enterococcus faecium are sensitive to $\mathrm{W}-n \mathrm{C}_{12}-\mathrm{W}$. Meropenem resistant Pseudomonas aeruginosa and multidrug resistant Klebsiella pneumoniae are also sensitive to $\mathrm{W}-n \mathrm{C}_{12}-\mathrm{W}$. The low toxicity of $\mathrm{W}-n \mathrm{C}_{12}-\mathrm{W}$ to mammalian cells and its potency both suggest $\mathrm{W}-n \mathrm{C}_{12}-\mathrm{W}^{\prime} \mathrm{s}$ potential as a drug candidate.

\section{Experimental Section}

\subsection{Planar Bilayer Conductance}

Membranes were formed by painting lipid solutions (asolectin from sorbean dissolved in $n$-decane, $25 \mathrm{mg} \cdot \mathrm{mL}^{-1}$, from Avanti Polar Lipids; Alabaster, AL, USA) over a $200 \mu \mathrm{M}$ aperture separating two chambers containing $3 \mathrm{~mL}$ buffer solutions $(450 \mathrm{mM} \mathrm{KCl}, 10 \mathrm{mM}$ HEPES, $\mathrm{pH}=7.00)$. The appropriate transporter $(21 \mu \mathrm{L}$ of a DMSO solution) was then added into the cis chamber (the side of the membrane that hosts the input electrode) to yield a final concentration of $7 \mu \mathrm{M}$. Working in a Faraday cage (Warner Instruments, Hamden, CT, USA) at room temperature, specific potentials were applied between two electrodes immersed in the two buffer solutions. The resulting currents were amplified (amplifier BC-525 D, from Warner Instruments), filtered with a 4-pole Bessel filter at $1 \mathrm{kHz}$, digitized by Digitizer (Digidata 1322A from Axon Instruments, Burlingame, CA, USA). The data were analyzed later using Clampfit 9.2 (Axon Instruments).

\subsection{Fluorescence Assays}

To test the membrane permeability of $S$. aureus, the bacteria were first grown in an incubator/shaker overnight from one CFU in media ( $\left.37^{\circ} \mathrm{C} ; 200 \mathrm{RPM}\right)$. S. aureus was then knocked back to O.D. $=0.550(\lambda=600 \mathrm{~nm})$ before use. Cells were added to a sterile test tube followed by either of the following treatments: Triton X-100, DMSA or compounds 1, 2, and 6. Compounds 1, 2, and 6 were added at concentrations of $0.5,1,2,4,8,16$ and $32 \mu \mathrm{M}$ and incubated $\left(37^{\circ} \mathrm{C} ; 200 \mathrm{RPM}\right)$. The concentration of DMSO was kept constant at $0.5 \% \mathrm{v} / \mathrm{v}$ in each case. After incubation $(30 \mathrm{~min}$.) the cells were washed by centrifugation 
at $3000 \times g$ for $5 \mathrm{~min}$ and re-suspended in sterile phosphate-buffered saline (PBS Sigma Aldrich BioPerformance Certified). Propidium iodide ( $30 \mu \mathrm{M}$, Thermo-Fischer) was added to the S. aureus cells in PBS media, mixed by vortexing and incubated $\left(37^{\circ} \mathrm{C} ; 200 \mathrm{RPM}\right)$. After $30 \mathrm{~min}$, the cells were loaded into a cuvette. Fluorescence data were collected by excitation at $493 \mathrm{~nm}$ and emission at $636 \mathrm{~nm}$. The average readings from three separate experiments are reported herein in graphical format (Figure 6).

\subsection{Determination of Minimum Inhibitory Concentrations (MICs)}

The MIC values for each compound and organism combination were determined using standard protocols $[24,38]$.

\subsection{Compound Preparation General Procedures}

The preparation of compounds 1-6 has previously been reported [24].

- Procedure 1. Coupling with HBTU

The $t$-butyl carbamate-protected (Boc-protected) amino acids and HBTU (2.1 equivalents) were dissolved in $10 \mathrm{~mL}$ anhydrous DMF with diisopropylethylamine (4.0 equivalents for the neutral diamines; 60 equivalents for diamine dihydrochlorides). The reaction was stirred overnight at room temperature under Argon. EtOAc $(75 \mathrm{~mL})$ was added and mixture was washed with $1 \mathrm{M} \mathrm{NaHSO}_{4}(2 \times 75 \mathrm{~mL}), 5 \% \mathrm{NaHCO}_{3}(3 \times 50 \mathrm{~mL})$, and brine. The organic layer was dried by filtration through a $\mathrm{MgSO}_{4} /$ celite plug and the solvent removed in vacuo. The Boc-protected bis(amino acid) was used without further purification or was crystallized/precipitated from $\mathrm{CH}_{2} \mathrm{Cl}_{2}$ /hexanes.

\section{- $\quad$ Procedure 2. Boc Deprotection with $\mathrm{HCl} /$ Dioxane}

The Boc-protected bis(aminoamide) deprotection was carried out by using $\mathrm{HCl}$ (10 equiv) in dioxane $/ \mathrm{CH}_{3} \mathrm{OH}$ and the product was obtained by precipitation and trituration with cold $\mathrm{CH}_{2} \mathrm{Cl}_{2}$.

- Procedure 3. Boc Deprotection with TFA

Boc-protected bis(aminoamide) deprotection was carried out by using 10 or more equivalents of TFA neat or in $\mathrm{CH}_{2} \mathrm{Cl}_{2}$. The product was obtained by removal of the solvent and TFA in vacuo. The product was used without further purification or recrystallized from $\mathrm{CH}_{3} \mathrm{OH} / \mathrm{CHCl}_{3} /$ hexanes.

- Procedure 4. Cbz Deprotection

The Cbz-protected amine was dissolved in absolute $\mathrm{EtOH}$ to which 0.1 molar equivalents of $10 \% \mathrm{Pd} / \mathrm{C}$ was added. The mixture was shaken on a Parr shaker at $60 \mathrm{psi}$ for $4 \mathrm{~h}$, then filtered through celite and the solvent was removed in vacuo.

- Procedure 5. RO-t-Bu Deprotection with TFA

See general procedure 3 .

- Procedure 6. $\mathrm{RO}-\mathrm{CH}_{2} \mathrm{Ph}$ (RO-Bn) Deprotection

See general procedure 4 .

Di-t-butyl ((2S,2'S)-(1,3-phenylenebis(azanediyl))bis(1-oxo-3-phenylpropane-2,1,diyl)) dicarbamate (Boc-F-mPh-F-Boc)

7a was prepared according to general procedure 1 using 1,3-phenylenediamine $(0.150 \mathrm{mg}, 1.39$ $\mathrm{mmol}$ ) and Boc-L-Phe-OH. White powder (7a, $0.80 \mathrm{~g}, 96 \%$ yield). ${ }^{1} \mathrm{H}-\mathrm{NMR}: 1.37$ (s, 18H, $\left.\left(\mathrm{CH}_{3}\right)_{3}\right), 2.90-3.20\left(\mathrm{~m}, 4 \mathrm{H}, \beta \mathrm{CH}_{2}\right), 4.73(\mathrm{~m}, 2 \mathrm{H}, \alpha \mathrm{CH}), 5.74(\mathrm{br}, 2 \mathrm{H}, \mathrm{Boc}-\mathrm{NH}), 6.92(\mathrm{~m}, 1 \mathrm{H}$, phenyl H5), $7.04(\mathrm{~m}, 2 \mathrm{H}$, phenyl $\mathrm{H} 4, \mathrm{H} 6), 7.20\left(\mathrm{~m}, 10 \mathrm{H}, \mathrm{C}_{6} \mathrm{H}_{5}\right), 7.61(\mathrm{~s}, 1 \mathrm{H}$, phenyl $\mathrm{H} 2)$, 8.98 (br, 2H, PhNHCO-). ${ }^{13}$ C-NMR: 28.22, 38.57, 56.41, 80.14, 111.73, 115.63, 126.63, 128.39, $128.77,129.17,136.62,137.90,156.14,170.43$.

(2S,2'S)-1,1'-(1,3-phenylenebis(azanediyl))bis(1-oxo-3-phenylpropan-2-aminium) chloride (F-mPh-F) 
7, was prepared according to general procedure 2 using $7 \mathrm{a}(550 \mathrm{mg}, 0.913 \mathrm{mmol})$. White powder $\left(0.40 \mathrm{~g}, 93 \%\right.$ yield). ${ }^{1} \mathrm{H}-\mathrm{NMR}\left(\mathrm{CD}_{3} \mathrm{OD}\right): 3.14-3.34\left(\mathrm{~m}, 4 \mathrm{H}, \beta \mathrm{CH}_{2}\right), 4.26(\mathrm{t}, J=7.3 \mathrm{~Hz}$, $2 \mathrm{H}, \alpha \mathrm{CH}), 7.26-7.35\left(\mathrm{~m}, 13 \mathrm{H}\right.$, phenyl H4-6, $\left.\mathrm{C}_{6} \mathrm{H}_{5}\right), 7.90(\mathrm{t}, J=1.7 \mathrm{~Hz}, 1 \mathrm{H}$, phenyl H2). ${ }^{13} \mathrm{C}-\mathrm{NMR}\left(\mathrm{CD}_{3} \mathrm{OD}\right): 38.76,56.41,113.14,117.53,128.88,130.11,130.33,130.64,135.53,139.42$, 167.93. Mass spectrum, calculated for free base $\mathrm{C}_{24} \mathrm{H}_{26} \mathrm{~N}_{4} \mathrm{O}_{2}$. Found $\mathrm{m} / \mathrm{z} 403.22(\mathrm{M}+1)$.

Di-t-butyl ((2S,2'S)-(1,3-phenylenebis(azanediyl))bis(3-(4-(benzyloxy)phenyl)-1-oxopropane-2,1diyl))dicarbamate (Boc-Y(Bn)-mPh-Y(Bn)-Boc)

8a, was prepared according to general procedure 1 using 1,3-phenylenediamine $(0.150 \mathrm{mg}$, $1.39 \mathrm{mmol}$ ) and Boc-L-Tyr-(OBn)-OH. White powder (8a, $1.10 \mathrm{~g}, 97 \%$ yield). ${ }^{1} \mathrm{H}-\mathrm{NMR}: 1.38$ $\left(\mathrm{s}, 18 \mathrm{H},\left(\mathrm{CH}_{3}\right)_{3}\right), 2.83-3.17\left(\mathrm{~m}, 4 \mathrm{H}, \beta_{\mathrm{CH}}\right), 4.70(\mathrm{~m}, 2 \mathrm{H}, \alpha \mathrm{CH}), 4.94\left(\mathrm{~s}, 4 \mathrm{H}, \mathrm{CH}_{2} \mathrm{Ph}\right), 5.74(\mathrm{br}$, 2H, Boc-NH), $6.84(\mathrm{~d}, J=8.4 \mathrm{~Hz}, 4 \mathrm{H}$, phenolic H2, H6), $6.91(\mathrm{~m}, 1 \mathrm{H}$, phenyl H5), $7.04(\mathrm{~m}$, $2 \mathrm{H}$, phenyl H4, H6), $7.12(\mathrm{~d}, \mathrm{~J}=8.4 \mathrm{~Hz}, 4 \mathrm{H}$, phenolic $\mathrm{H} 3, \mathrm{H} 5), 7.20-7.37\left(\mathrm{~m}, 10 \mathrm{H}, \mathrm{C}_{6} \mathrm{H}_{5}\right)$, 7.67 (s, 1H, phenyl H2), 9.06 (br, 2H, PhNHCO-). ${ }^{13} \mathrm{C}-\mathrm{NMR}: 28.22,37.69,56.47,69.72,80.12$, $111.61,114.69,115.52,127.29,127.72,128.36,128.76,128.84,130.20,136.85,137.93,156.18$, $157.53,170.51$.

Di-t-butyl ((2S,2'S)-(1,3-phenylene-bis(azanediyl))bis(3-(4-hydroxyphenyl)-1-oxopropane-2,1-diyl)) dicarbamate (Boc-Y-mPh-Y-Boc)

$8 \mathbf{a}$, was prepared according to general procedure 6 using $8 \mathbf{a}(1.00 \mathrm{~g}, 1.23 \mathrm{mmol})$. White solid $\left(8,0.77 \mathrm{~g}, 99 \%\right.$ yield). ${ }^{1} \mathrm{H}-\mathrm{NMR}\left(2: 1 \mathrm{CD}_{3} \mathrm{OD} / \mathrm{CDCl}_{3}\right): 1.39\left(\mathrm{~s}, 18 \mathrm{H},\left(\mathrm{CH}_{3}\right)_{3}\right), 2.82-3.11(\mathrm{~m}$, $\left.4 \mathrm{H}, \beta \mathrm{CH}_{2}\right), 4.43(\mathrm{~m}, 2 \mathrm{H}, \alpha \mathrm{CH}), 6.75(\mathrm{~d}, J=6.4 \mathrm{~Hz}, 4 \mathrm{H}$, phenolic $\mathrm{H} 2, \mathrm{H} 6), 7.05(\mathrm{~d}, J=6.5 \mathrm{~Hz}$, $4 \mathrm{H}$, phenolic H3, H5), 7.14-7.35 (m, 3H, phenyl H4-H6), 7.69 (s, 1H, phenyl H2), 9.64 (br, 2H, PhNHCO-). ${ }^{13}$ C-NMR: 28.68, 38.71, 57.66, 80.64, 113.29, 116.05, 117.30, 128.37, 129.77, $131.11,139.07,156.59,157.03,172.31$.

(2S,2'S)-1,1'-(1,3-phenylenebis(azanediyl))bis(3-(4-hydroxyphenyl)-1-oxopropan-2-aminium) chloride $(Y-m P h-Y)$

8, was prepared according to general procedure 2 using $8 \mathbf{a}(770 \mathrm{mg}, 1.21 \mathrm{mmol})$. Off-white solid (0.61 g, 99\% yield). ${ }^{1} \mathrm{H}-\mathrm{NMR}\left(\mathrm{CD}_{3} \mathrm{OD}\right): 3.15-3.34\left(\mathrm{~m}, 4 \mathrm{H}, \beta \mathrm{CH}_{2}\right), 3.70(\mathrm{~s}, 2 \mathrm{H}, \mathrm{ArOH})$, $4.39(\mathrm{~m}, 2 \mathrm{H}, \alpha \mathrm{CH}), 6.76(\mathrm{~m}, 4 \mathrm{H}$, phenolic $\mathrm{H} 2, \mathrm{H} 6), 7.09-7.33(\mathrm{~m}, 7 \mathrm{H}$, phenyl H4-6, phenolic $\mathrm{H} 3, \mathrm{H} 5), 8.09$ (s, 1H, phenyl H2), 8.39 (br, 2H, PhNHCO-). ${ }^{13} \mathrm{C}-\mathrm{NMR}\left(\mathrm{CD}_{3} \mathrm{OD}\right): 37.90$, $56.78,113.56,116.93,117.79,126.13,130.41,132.04,139.34,158.03,168.36$. Mass spectrum, calculated for free base $\mathrm{C}_{24} \mathrm{H}_{26} \mathrm{~N}_{4} \mathrm{O}_{4}$. Found $\mathrm{m} / \mathrm{z} 435.22(\mathrm{M}+1)$.

Di-t-butyl ((2S,2'S)-(1,3-phenylenebis(azanediyl))bis(4-methyl-1-oxopentane-2,1-diyl)) dicarbamate (Boc-L-mPh-L-Boc)

9a, was prepared according to general procedure 1 using 1,3- phenylenediamine $(0.150 \mathrm{mg}$, $1.39 \mathrm{mmol})$ and Boc-L-Leu-OH. White powder $\left(0.66 \mathrm{~g}, 89 \%\right.$ yield). ${ }^{1} \mathrm{H}-\mathrm{NMR}: 0.94$ (dd, $\left.J=6.9,6.7 \mathrm{~Hz}, 12 \mathrm{H}, \mathrm{CH}\left(\mathrm{CH}_{3}\right)_{2}\right), 1.47\left(\mathrm{~s}, 18 \mathrm{H},\left(\mathrm{CH}_{3}\right)_{3}\right), 1.55-1.85\left(\mathrm{~m}, 6 \mathrm{H}, \beta \mathrm{CH}_{2}, \gamma \mathrm{CH}\right), 4.48$ $(\mathrm{m}, 2 \mathrm{H}, \alpha \mathrm{CH}), 5.73(\mathrm{~m}, 2 \mathrm{H}$, Boc-NH), $6.85(\mathrm{~m}, 1 \mathrm{H}$, phenyl H5), $7.04(\mathrm{~m}, 2 \mathrm{H}$, phenyl H4, H6), 7.74 (s, 1H, phenyl H2), 9.30 (s, 2H, PhNHCO-). ${ }^{13}$ C-NMR: 21.42, 23.07, 24.61, 28.34, 41.15, 53.80, 80.02, 111.34, 115.03, 128.52, 156.42, 171.73 .

(2S,2'S)-1,1'-(1,3-phenylenebis(azanediyl))bis(4-methyl-1-oxopentan-2-aminium) chloride (L-mPh-L)

9, was prepared according to general procedure 2 using $9 \mathrm{a}(500 \mathrm{mg}, 0.935 \mathrm{mmol})$. White powder $\left(0.35 \mathrm{~g}, 91 \%\right.$ yield). ${ }^{1} \mathrm{H}-\mathrm{NMR}\left(\mathrm{CD}_{3} \mathrm{OD}\right): 1.04\left(\mathrm{~d}, J=5.8 \mathrm{~Hz}, 12 \mathrm{H}, \mathrm{CH}\left(\mathrm{CH}_{3}\right)_{2}\right)$, 1.71-1.85 (m, $\left.6 \mathrm{H}, \beta_{\mathrm{CH}}, \gamma \mathrm{CH}\right), 4.06(\mathrm{t}, J=7.0 \mathrm{~Hz}, 2 \mathrm{H}, \alpha \mathrm{CH}), 7.29-7.34(\mathrm{~m}, 1 \mathrm{H}$, phenyl H5), 7.39-7.42 (m, 2H, phenyl H4, H6), $8.08\left(\mathrm{t}, \mathrm{J}=1.9 \mathrm{~Hz}, 1 \mathrm{H}\right.$, phenyl H2). ${ }^{13} \mathrm{C}-\mathrm{NMR}\left(\mathrm{CD}_{3} \mathrm{OD}\right)$ : 22.14, 23.28, 25.57, 41.77, 53.76, 113.11, 117.49, 130.49, 138.32, 139.73, 169.15. Mass spectrum, calculated for free base $\mathrm{C}_{18} \mathrm{H}_{30} \mathrm{~N}_{4} \mathrm{O}_{2}$. Found $\mathrm{m} / \mathrm{z} 335.25(\mathrm{M}+1)$.

Di-t-butyl ((2S,2'S)-(1,3-phenylenebis(azanediyl))bis(1-oxopropane-2,1-diyl))dicarbamate (Boc-A$m P h-A-B o c)$

10a, was prepared according to general procedure 1 using 1,3-phenylenediamine $(0.100 \mathrm{mg}$, $0.92 \mathrm{mmol})$ and Boc-L-Ala-OH. White powder $(0.35 \mathrm{~g}, 84 \%$ yield $), \mathrm{mp} 159-161{ }^{\circ} \mathrm{C} .{ }^{1} \mathrm{H}-$ NMR: $1.42\left(\mathrm{~d}, \mathrm{~J}=7.0 \mathrm{~Hz}, 6 \mathrm{H}, \beta \mathrm{CH}_{3}\right), 1.47\left(\mathrm{~s}, 18 \mathrm{H},\left(\mathrm{CH}_{3}\right)_{3}\right), 4.37(\mathrm{~m}, 2 \mathrm{H}, \alpha \mathrm{CH}), 5.31(\mathrm{~m}, 2 \mathrm{H}$, Boc-NH), 7.10 (m, 1H, phenyl H5), 7.19 (m, 2H, phenyl H4, H6), $7.60(\mathrm{~s}, 1 \mathrm{H}$, phenyl H2), 
8.65 (s, 2H, PhNHCO-). ${ }^{13}$ C-NMR: 17.98, 28.35, 50.81, 80.46, 111.28, 115.50, 129.16, 138.22, $156.13,171.39,188.71$.

(2S,2'S)-1,1'-(1,3-phenylenebis(azanediyl))bis(1-oxopropan-2-aminium) chloride ( $A$-mPh- $A$ )

10, was prepared according to general procedure 2 using 10a (105 $\mathrm{mg}, 0.23 \mathrm{mmol})$. White powder (0.07 g, 93\% yield), mp $195{ }^{\circ} \mathrm{C}$ (dec.). ${ }^{1} \mathrm{H}-\mathrm{NMR}\left(\mathrm{CD}_{3} \mathrm{OD}\right): 1.60$ (d, J= $7.0 \mathrm{~Hz}, 6 \mathrm{H}$, $\left.\beta_{\mathrm{CH}_{3}}\right), 4.08(\mathrm{q}, \mathrm{J}=7.0 \mathrm{~Hz}, 2 \mathrm{H}, \alpha \mathrm{CH}), 7.22-7.39(\mathrm{~m}, 3 \mathrm{H}$, phenyl H4, H5, H6), $8.05(\mathrm{~m}, 1 \mathrm{H}$, phenyl H2). ${ }^{13} \mathrm{C}-\mathrm{NMR}\left(\mathrm{CD}_{3} \mathrm{OD}\right): 17.89,51.06,112.94,117.34,130.50,139.86,169.48$. Mass spectrum, calculated for free base $\mathrm{C}_{12} \mathrm{H}_{18} \mathrm{~N}_{4} \mathrm{O}_{2}$. Found $\mathrm{m} / \mathrm{z} 251.16(\mathrm{M}+1)$.

Di-t-butyl-(2S,2'S)-2,2'-((1,3-phenylenebis(azanediyl))bis(carbonyl))bis-(pyrrolidine-1- carboxylate) (Boc-P-mPh-P-Boc)

11a, was prepared according to general procedure 1 using 1,3-phenylenediamine (0.150 $\mathrm{mg}, 1.39 \mathrm{mmol})$ and Boc-L-Pro-OH. White powder $(0.57 \mathrm{~g}, 81 \%$ yield $), \mathrm{mp} 121^{\circ} \mathrm{C}$ (dec. $)$. ${ }^{1} \mathrm{H}-\mathrm{NMR}: 1.49\left(\mathrm{~s}, 18 \mathrm{H},\left(\mathrm{CH}_{3}\right)_{3}\right), 1.85-2.55\left(\mathrm{~m}, 8 \mathrm{H}, \mathrm{CH}_{2}, \gamma \mathrm{CH}_{2}\right), 3.31-3.67\left(\mathrm{~m}, 4 \mathrm{H}, \delta \mathrm{CH}_{2}\right)$ 4.30-4.48 (m, 2H, $\alpha \mathrm{CH}), 7.06-7.52$ (m, 3H, phenyl H4-6), 7.62 (br, 1H, phenyl H2), 9.34 (br, 2H, PhNHCO-). ${ }^{13}$ C-NMR: 24.58, 28.47, 47.28, 60.71, 80.83, 110.91, 115.37, 129.23, 138.71, $156.32,170.35$.

(2S,2'S)-2,2'-((1,3-phenylenebis(azanediyl))bis(carbonyl))bis(pyrrolidin-1-ium) 2,2,2- trifluoroacetate $(P-m P h-P)$

11, was prepared according to general procedure 3 using 11a (400 mg, $0.80 \mathrm{mmol})$. White powder $(0.39 \mathrm{~g}, 91 \%$ yield $), \mathrm{mp} 80{ }^{\circ} \mathrm{C}$ (dec.). ${ }^{1} \mathrm{H}-\mathrm{NMR}\left(\mathrm{DMSO}-\mathrm{d}_{6}\right): 1.87-2.04\left(\mathrm{~m}, 6 \mathrm{H}, \gamma \mathrm{CH}_{2}\right.$, $\beta \mathrm{CH}), 2.32-2.43(\mathrm{~m}, 2 \mathrm{H}, \beta \mathrm{CH}), 3.30\left(\mathrm{~m}, 4 \mathrm{H}, \delta \mathrm{CH}_{2}\right), 4.41(\mathrm{~m}, 2 \mathrm{H}, \alpha \mathrm{CH}), 7.35(\mathrm{~m}, 3 \mathrm{H}$, phenyl H4-6), 8.07 (s, 1H, phenyl H2). 8.79 (br, 2H, $\mathrm{NH}_{2}^{+}$), 9.90 (br, 2H, $\mathrm{NH}_{2}^{+}$), 10.77 (s, 2H, PhNHCO-). ${ }^{13}$ C- NMR (DMSO-d 6 ): 23.52, 29.65, 45.69, 59.63, 110.69, 115.16, 129.35, 138.59, $158.65,166.93$. Mass spectrum, calculated for free base $\mathrm{C}_{16} \mathrm{H}_{22} \mathrm{~N}_{4} \mathrm{O}_{2}$. Found $\mathrm{m} / \mathrm{z} 303.19$ $(\mathrm{M}+1)$.

Di-t-butyl ((2S,2'S,3R,3'R)-(1,3-phenylene-bis(azanediyl))bis(3-(benzyloxy)-1-oxobutane-2,1-diyl)) dicarbamate (Boc- $T(B n)-m P h-T(B n)-B o c)$

12a, was prepared according to general procedure 1 using 1,3-phenylenediamine (150 mg, $1.39 \mathrm{mmol})$ and Boc-L-Thr-(OBn)-OH. White powder (0.90 g, 94\% yield). ${ }^{1} \mathrm{H}-\mathrm{NMR}: 1.21$ $\left(\mathrm{d}, \mathrm{J}: 6.4 \mathrm{~Hz}, 6 \mathrm{H}, \gamma \mathrm{CH}_{3}\right), 1.44\left(\mathrm{~s}, 18 \mathrm{H},\left(\mathrm{CH}_{3}\right)_{3}\right), 4.15(\mathrm{~m}, 2 \mathrm{H}, \mathrm{BCH}), 4.44-4.61(\mathrm{~m}, 6 \mathrm{H}, \alpha \mathrm{CH}$, $\left.\mathrm{OCH}_{2} \mathrm{Ph}\right), 5.83(\mathrm{~d}, \mathrm{~J}=6.8 \mathrm{~Hz}, 2 \mathrm{H}, \mathrm{Boc}-\mathrm{NH}), 7.05-7.31(\mathrm{~m}, 13 \mathrm{H}, \mathrm{OBn}$, phenyl H4-6), 7.74 (s, 1H, phenyl H2), 8.80 (br, 2H, PhNHCO-). ${ }^{13} \mathrm{C}-\mathrm{NMR}: 15.35,27.84,58.16,70.89,74.43,79.58$, 111.07, 115.36, 127.28, 127.83, 127.98, 128.78, 137.39, 137.69, 155.63, 168.18.

$\left(2 S, 2^{\prime} S, 3 R, 3^{\prime} R\right)-1,1^{\prime}-(1,3-p h e n y l e n e b i s($ azanediyl))bis(3-hydroxy-1-oxobutan-2-aminium) 2,2,2-trifluoroacetate ( $T$ - $m P h-T)$

12, was prepared by benzyl deprotection from 12a $(0.9 \mathrm{~g}, 1.30 \mathrm{mmol})$ according to general procedure 6 (0.66 g, 99\% yield) followed by Boc deprotection by general procedure 3 . Off-white solid (0.36 g, 93\% yield), mp $85{ }^{\circ} \mathrm{C}$ (dec.). ${ }^{1} \mathrm{H}-\mathrm{NMR}\left(\mathrm{CD}_{3} \mathrm{OD}\right): 1.33$ (d, J = 6.4 Hz, $\left.6 \mathrm{H}, \gamma \mathrm{CH}_{3}\right), 3.81(\mathrm{~d}, J=6.2 \mathrm{~Hz}, 2 \mathrm{H}, \alpha \mathrm{CH}), 4.14(\mathrm{~m}, 2 \mathrm{H}, \beta \mathrm{CH}), 7.20-7.40(\mathrm{~m}, 3 \mathrm{H}$, phenyl H4-6), 8.07 (s, 1H, phenylH2). ${ }^{13} \mathrm{C}-\mathrm{NMR}\left(\mathrm{CD}_{3} \mathrm{OD}\right): 20.38,60.99,67.58,113.04,117.50,130.52$, $139.65,167.03$. Mass spectrum, calculated for free base $\mathrm{C}_{14} \mathrm{H}_{22} \mathrm{~N}_{4} \mathrm{O}_{4}$. Found $\mathrm{m} / \mathrm{z} 311.16$ $(\mathrm{M}+1)$.

Di-t-butyl((2S,2'S)-(1,3-phenylenebis(azanediyl))bis(6-benzylcarboxyamido-1-oxohexane-2,1-diyl)) dicarbamate (Boc-K(Cbz)-mPh-K(Cbz)-Boc)

13a, was prepared according to general procedure 1 using 1,3-phenylenediamine (150 mg, $1.39 \mathrm{mmol})$ and Boc-L-Lys-(NeCbz)-OH. Yellow solid (1.10 g, 95\% yield). ${ }^{1} \mathrm{H}-\mathrm{NMR}$ : 1.33 $1.55\left(\mathrm{~m}, 26 \mathrm{H},\left(\mathrm{CH}_{3}\right)_{3}, \gamma \mathrm{CH}_{2}, \delta \mathrm{CH}_{2}\right), 1.58-1.86\left(\mathrm{~m}, 4 \mathrm{H}, \beta_{\mathrm{CH}_{2}}\right), 3.13\left(\mathrm{~m}, 4 \mathrm{H}, \delta \mathrm{CH}_{2}\right), 4.29(\mathrm{~m}$, $\left.2 \mathrm{H}, \alpha \mathrm{CH}_{2}\right), 5.06$ (s, 4H, $\left.\mathrm{CH}_{2} \mathrm{Ph}\right), 5.59$ (br, 2H Cbz-NH), 5.92 (br, 2H, Boc-NH), $7.06(\mathrm{~m}, 1 \mathrm{H}$, phenyl H5), 7.23 (m, 12H, Cbz-ArH, phenyl H4, H6), 7.99 (s, 1H, phenyl H2), 9.18 (br, 2H PhNHCO-).

(5S,5'S)-6,6'-(1,3-phenylenebis(azanediyl))bis(6-oxohexane-1,5-diaminium) 2,2,2-trifluoroacetate 
13 was prepared according to general procedure 4 using 13a $(1.10 \mathrm{~g}, 1.32 \mathrm{mmol})$. Cbz deprotected product $13 \mathrm{~b}(0.60 \mathrm{~g}, 81 \%$ yield $)$ was used without further purification. Boc deprotection by general procedure 3 using $\mathbf{1 3 b}(600 \mathrm{mg}, 1.06 \mathrm{mmol})$ afforded $\mathrm{K}-\mathrm{mPh}-\mathrm{K}, \mathbf{1 3}$, as a yellow solid $(0.76 \mathrm{~g}, 87 \%$ yield $) .{ }^{1} \mathrm{H}-\mathrm{NMR}\left(\mathrm{CD}_{3} \mathrm{OD}\right): 1.58\left(\mathrm{~m}, 4 \mathrm{H}, \gamma \mathrm{CH}_{2}\right), 1.75(\mathrm{~m}, 4 \mathrm{H}$, $\left.\alpha \mathrm{CH}_{2}\right), 2.01\left(\mathrm{~m}, 4 \mathrm{H}, \beta \mathrm{CH}_{2}\right), 2.98\left(\mathrm{t}, J=7.6 \mathrm{~Hz}, 4 \mathrm{H}, \varepsilon \mathrm{CH}_{2}\right), 4.09(\mathrm{t}, J=6.4 \mathrm{~Hz}, 2 \mathrm{H}, \alpha \mathrm{CH})$, 7.28-7.40 (m, 3H, phenyl H4-6), 8.08 (s, $1 \mathrm{H}$, phenyl H2). ${ }^{13} \mathrm{C}-\mathrm{NMR}\left(\mathrm{CD}_{3} \mathrm{OD}\right): 23.05,28.20$, $32.29,40.35,54.96,113.26,117.62,130.54,139.70,162.95,163.49$, 168.67. Mass spectrum, calculated for free base $\mathrm{C}_{18} \mathrm{H}_{32} \mathrm{~N}_{6} \mathrm{O}_{2}$. Found $\mathrm{m} / \mathrm{z} 365.25(\mathrm{M}+1)$.

\section{Conclusions}

Herein we report the synthesis of compounds having the general formula Aaa-linkerAaa where the amino acids were chosen from among the common 20. Derivatives other than Aaa $=\operatorname{Trp}$, i.e., the bis(tryptophan) compounds, showed no activity as antimicrobials. This highlights the importance of tryptophan and the novelty of the bis(tryptophan) compound family developed, further supporting the hypothesized mechanism. To summarize, we report three novel findings. First, a range of bacteria succumb to the activity of various bis(tryptophan) compounds. W- $n \mathrm{C}_{12}-\mathrm{W}$ (6) shows a MIC value of $4 \mu \mathrm{M}$ against $S$. aureus 1199B and MIC values of $9 \mu \mathrm{M}$ and $18 \mu \mathrm{M}$ respectively against E. faecium VanA and E. faecalis Van B, which are resistant to multiple antimicrobials, including vancomycin. Second, evidence has been obtained that clearly shows the formation of pores by BTs in planar bilayers. The formation of ion-conducting pores in bilayers does not guarantee identical behavior in Gram negative or Gram positive membranes. However, confirmation of channel formation is consistent with the hypothesis that membrane permeability is enhanced by these ionophores and that the disruption of ion balance as a result may hinder efflux pump function as well as other ion-regulated enzymatic processes. Fluorescence studies also support the hypothesis of enhanced membrane penetration.

Third, the low toxicity bis(tryptophan) compounds having either meta-phenylene or $n$-dodecylene linkers function as effective adjuvants to enhance the properties of FDA approved antimicrobials against organisms such as S. aureus. An example reported herein shows a BT-mediated synergistic effect that enhances the potency of norfloxacin against S. aureus by 128 -fold.

Finally, $\mathrm{W}-n \mathrm{C}_{12}-\mathrm{W}$ is both a membrane disruptor and an antibiotic per se as evidence by the propidium iodide experiments (Figure 6), the planar bilayer study, and its low MIC as shown in the in-depth screen. The meta-phenylene compounds are effective adjuvants as they form pores (Figure 2) and show synergistic activity (F-index $<0.5$ ).

Author Contributions: Conceptualization, G.G., J.M., M.P.; methodology, G.G., J.M., M.P.; software, n/a.; validation, G.G., M.P.; formal analysis, G.G., M.P.; investigation, H.G., M.G., J.M., S.N., M.P., S.Y.; data curation, G.G., M.P.; writing—original draft preparation, G.G., M.P.; writing—review and editing, G.G., M.G., M.P., G.G., M.G.; supervision, G.G.; project administration, G.G.; funding acquisition, G.G. All authors have read and agreed to the published version of the manuscript.

Funding: This research no additional funding outside of the NSF grant indicated in "Acknowledgements". No funding beyond the funding cited supported this project. The authors have filed patent applications that will be owned by the University of Missouri. These patents may or may not be licensed by one or more of the authors in the future for development.

Data Availability Statement: Data are contained within the article.

Acknowledgments: We thank the NSF for a grant CHE-1710549 that supported this work. We are also grateful to the NIH Preclinical Services for antimicrobial assay.

Conflicts of Interest: The authors declare no conflict of interest. 


\section{References}

1. CDC. Antibiotic Resistance Threats in the United States 2019; Department of Health and Human Services: Washington, DC, USA, 2019; p. 150.

2. Antibiotic/Antimicrobial Resistance (AR/AMR). Available online: https://www.cdc.gov/drugresistance/index.html (accessed on 17 July 2021).

3. World Health Organization. Global Antimicrobial Resistance and Use Surveillance System (GLASS) Report Early Implementation 2020; World Health Organization: New York, NY, USA, 2020; p. 134.

4. World Health Organization. Antimicrobial Resistance Global Report on Surveillance; WHO: Geneva, Switzerland, 2014.

5. Shlaes, D.M. Antibiotics: The Perfect Storm; Springer: New York, NY, USA, 2010; 106p.

6. Ling, L.L.; Schneider, T.; Peoples, A.J.; Spoering, A.L.; Engels, I.; Conlon, B.P.; Mueller, A.; Schäberle, T.F.; Hughes, D.E.; Epstein, S.; et al. A new antibiotic kills pathogens without detectable resistance. Nature 2015, 517, 455-459. [CrossRef]

7. WHO Publishes List of Bacteria for Which New Antibiotics Are Urgently Needed. Available online: https://www.who.int/ news-room/detail/27-02-2017-who-publishes-list-of-bacteria-for-which-new-antibiotics-are-urgently-needed (accessed on 31 May 2021).

8. Purdy Drew, K.R.; Sanders, L.K.; Culumber, Z.W.; Zribi, O.; Wong, G.C. Cationic amphiphiles increase activity of aminoglycoside antibiotic tobramycin in the presence of airway polyelectrolytes. J. Am. Chem. Soc. 2009, 131, 486-493. [CrossRef]

9. Bruno, M.J.; Rusinova, R.; Gleason, N.J.; Koeppe, R.E., II; Andersen, O.S. Interactions of drugs and amphiphiles with membranes: Modulation of lipid bilayer elastic properties by changes in acyl chain unsaturation and protonation. Faraday Discuss. 2013, 161, 461-480. [CrossRef]

10. Dalton, C.J.; Haxell, M.A.; McArthur, H.A.I.; Wax, R. (Eds.) Peptide Antibiotics: Discovery, Modes of Action, and Applications; Marcel Dekker: New York, NY, USA, 2002; 296p.

11. Cheah, S.E.; Li, J.; Tsuji, B.T.; Forrest, A.; Bulitta, J.B.; Nation, R.L. Colistin and Polymyxin B Dosage Regimens against Acinetobacter baumannii: Differences in Activity and the Emergence of Resistance. Antimicrob. Agents Chemother. 2016, 60, 3921-3933. [CrossRef] [PubMed]

12. Karaiskos, I.; Souli, M.; Galani, I.; Giamarellou, H. Colistin: Still a lifesaver for the 21st century? Expert Opin. Drug Metab. Toxicol. 2016, 13, 59-71. [CrossRef]

13. Yahav, D.; Farbman, L.; Leibovici, L.; Paul, M. Colistin: New lessons on an old antibiotic. Clin. Microbiol. Infect. 2012, 18, 18-29. [CrossRef]

14. Biswas, S.; Brunel, J.M.; Dubus, J.C.; Reynaud-Gaubert, M.; Rolain, J.M. Colistin: An update on the antibiotic of the 21st century. Expert Rev. Anti. Infect. Ther. 2012, 10, 917-934. [CrossRef]

15. Kumar, M.; Saha, S.; Subudhi, E. More Furious Than Ever: Escherichia coli-Acquired Co-resistance toward Colistin and Carbapenems. Clin. Infect. Dis. 2016, 63, 1267-1268.

16. Nicolet, S.; Goldenberger, D.; Schwede, T.; Page, M.; Creus, M. Plasmid-mediated colistin resistance in a patient infected with Klebsiella pneumoniae. Lancet Infect. Dis. 2016, 16, 998-999. [CrossRef]

17. Kadar, B.; Kocsis, B.; Toth, A.; Kristof, K.; Felso, P.; Kocsis, B.; Boddi, K.; Szabo, D. Colistin resistance associated with outer membrane protein change in Klebsiella pneumoniae and Enterobacter asburiae. Acta Microbiol. Immunol. Hung. 2017, 64, $217-227$. [CrossRef] [PubMed]

18. Jasim, R.; Baker, M.A.; Zhu, Y.; Han, M.; Schneider-Futschik, E.K.; Hussein, M.; Hoyer, D.; Li, J.; Velkov, T. A Comparative Study of Outer Membrane Proteome between Paired Colistin-Susceptible and Extremely Colistin-Resistant Klebsiella pneumoniae Strains. ACS Infect. Dis. 2018, 4, 1692-1704. [CrossRef] [PubMed]

19. Liu, X.; Zhao, M.; Chen, Y.; Bian, X.; Li, Y.; Shi, J.; Zhang, J. Synergistic killing by meropenem and colistin combination of carbapenem-resistant Acinetobacter baumannii isolates from Chinese patients in an in vitro pharmacokinetic/pharmacodynamic model. Int. J. Antimicrob. Agents 2016, 48, 559-563. [CrossRef] [PubMed]

20. Albur, M.S.; Noel, A.; Bowker, K.; MacGowan, A. The combination of colistin and fosfomycin is synergistic against NDM-1producing Enterobacteriaceae in in vitro pharmacokinetic/pharmacodynamic model experiments. Int. J. Antimicrob. Agents 2015, 46, 560-567. [CrossRef] [PubMed]

21. Naghmouchi, K.; Baah, J.; Hober, D.; Jouy, E.; Rubrecht, C.; Sane, F.; Drider, D. Synergistic effect between colistin and bacteriocins in controlling Gram-negative pathogens and their potential to reduce antibiotic toxicity in mammalian epithelial cells. Antimicrob. Agents Chemother. 2013, 57, 2719-2725. [CrossRef] [PubMed]

22. Falagas, M.E.; Rafailidis, P.I. Nephrotoxicity of colistin: New insight into an old antibiotic. Clin. Infect. Dis. 2009, 48, 1729-1731. [CrossRef] [PubMed]

23. Dudhani, R.V.; Nation, R.L.; Li, J. Evaluating the stability of colistin and colistin methanesulphonate in human plasma under different conditions of storage. J Antimicrob. Chemother. 2010, 65, 1412-1415. [CrossRef]

24. Gokel, G.W.; Dishong, D.M.; Diamond, C.J. Lariat Ethers. Synthesis and Cation Binding of Macrocyclic Polyethers Possessing Axially Disposed Secondary Donor Groups. J.C.S. Chem. Commun. 1980, 22, 1053-1054.

25. Gokel, G.W.; Echegoyen, L. Advances in Bio-Organic Frontiers; Dugas, H., Ed.; Springer: Berlin, Germany, 1990 ; Volume 1, p. 116.

26. Gokel, G.W.; Schall, O.F. Lariat Ethers. In Comprehensive Supramolecular Chemistry; Gokel, G.W., Ed.; Pergamon: Oxford, UK, 1996; Volume 1, p. 97. 
27. Gokel, G.W. Hydraphiles: Design, Synthesis, and Analysis of a Family of Synthetic, Cation-Conducting Channels. Chem. Commun. 2000, 1, 1-9. [CrossRef]

28. Gandour, R.D.; Fronczek, F.R.; Gatto, V.J.; Minganti, C.; Schultz, R.A.; White, B.D.; Arnold, K.A.; Mazzocchi, D.; Miller, S.R.; Gokel, G.W. Solid-State Structural Chemistry of Lariat Ether and BiBLE Cation Complexes: Metal Ion Identity and Coordination Number Determine Cavity Size. J. Am. Chem. Soc. 1986, 108, 4078-4088. [CrossRef]

29. Hernandez, J.C.; Trafton, J.E.; Gokel, G.W. A direct comparison of extraction and homogeneous binding constants as predictors of efficacy in alkali metal cation transport. Tetrahedron Lett. 1991, 32, 6269-6272. [CrossRef]

30. Negin, S.; Patel, M.B.; Gokel, M.R.; Meisel, J.W.; Gokel, G.W. Antibiotic Potency against E. coli Is Enhanced by Channel-Forming Alkyl Lariat Ethers. ChemBioChem 2016, 17, 2153-2161. [CrossRef] [PubMed]

31. Gokel, G.W.; Negin, S. Synthetic Membrane Active Amphiphiles. Adv. Drug Deliv. Rev. 2012, 64, 784-796. [CrossRef] [PubMed]

32. Atkins, J.L.; Patel, M.B.; Cusumano, Z.; Gokel, G.W. Enhancement of antimicrobial activity by synthetic ion channel synergy. Chem. Commun. 2010, 46, 8166-8167. [CrossRef]

33. Gokel, G.W.; Gokel, M.R.; Negin, S.; Patel, M.B. Molecules That Inhibit Efflux Pumps in Multi-Drug Resistant Bacteria and Uses Thereof. U.S. Patent 10,463,044 B2, 5 November 2019.

34. Meisel, J.W.; Patel, M.B.; Garrad, E.; Gokel, G.W. Reversal of Tetracycline Resistance in Escherichia coli by Non-cytotoxic bis(Tryptophan)s. J. Am. Chem. Soc. 2016, 138, 10571-10577. [CrossRef]

35. de Planque, M.R.; Bonev, B.B.; Demmers, J.A.; Greathouse, D.V.; Koeppe, R.E., II; Separovic, F.; Watts, A.; Killian, J.A. Interfacial anchor properties of tryptophan residues in transmembrane peptides can dominate over hydrophobic matching effects in peptide-lipid interactions. Biochemistry 2003, 42, 5341-5348. [CrossRef]

36. de Planque, M.R.R.; Kruijtzer, J.A.W.; Liskamp, R.M.J.; Marsh, D.; Greathouse, D.V.; Koeppe, R.E., II; De Kruijff, B.; Killian, J.A. Different membrane anchoring positions of tryptophan and lysine in synthetic transmembrane $\alpha$-helical peptides. J. Biol. Chem. 1999, 274, 20839-20846. [CrossRef]

37. Wallace, B.A. Gramicidin channels and pores. Annu. Rev. Biophys. 1990, 19, 127-157. [CrossRef] [PubMed]

38. Hu, W.; Lee, K.-C.; Cross, T.A. Tryptophans in membrane proteins: Indole ring orientations and functional implications in the gramicidin channel. Biochemistry 1993, 32, 7035-7047. [CrossRef]

39. Doyle, D.A.; Cabral, J.M.; Pfuetzner, R.A.; Kuo, A.; Gulbis, J.M.; Cohen, S.L.; Chait, B.T.; MacKinnon, R. The structure of the potassium channel: Molecular basis of $\mathrm{K}^{+}$conduction and selectivity. Science 1998, 280, 69-77. [CrossRef]

40. Abel, E.; Fedders, M.F.; Gokel, G.W. Vesicle formation from $N$-alkylindoles: Implications for tryptophan-water interactions. J. Am. Chem. Soc. 1995, 117, 1265-1270. [CrossRef]

41. Weiss, T.M.; van der Wel, P.C.; Killian, J.A.; Koeppe, R.E., II; Huang, H.W. Hydrophobic mismatch between helices and lipid bilayers. Biophys. J. 2003, 84, 379-385. [CrossRef]

42. Wimley, W.C. Describing the mechanism of antimicrobial peptide action with the interfacial activity model. ACS Chem. Biol. 2010, 5, 905-917. [CrossRef] [PubMed]

43. Sakmann, B.; Neher, E. Single-Channel Recording; Kluwer Academic Publishers: New York, NY, USA, 1995; 700p.

44. Yamamoto, T.; Umegawa, Y.; Yamagami, M.; Suzuki, T.; Tsuchikawa, H.; Hanashima, S.; Matsumori, N.; Murata, M. The Perpendicular Orientation of Amphotericin B Methyl Ester in Hydrated Lipid Bilayers Supports the Barrel-Stave Model. Biochemistry 2019, 58, 2282-2291. [CrossRef]

45. Cantor, R.S. Size distribution of barrel-stave aggregates of membrane peptides: Influence of the bilayer lateral pressure profile. Biophys. J. 2002, 82, 2520-2525. [CrossRef]

46. Yang, L.; Harroun, T.A.; Weiss, T.M.; Ding, L.; Huang, H.W. Barrel-stave model or toroidal model? A case study on melittin pores. Biophys. J. 2001, 81, 1475-1485. [CrossRef]

47. Providence, L.L.; Andersen, O.S.; Greathouse, D.V.; Koeppe, R.E., II; Bittman, R. Gramicidin channel function does not depend on phospholipid chirality. Biochemistry 1995, 34, 16404-16411. [CrossRef] [PubMed]

48. Ohki, S.; Arnold, K. Surface dielectric constant, surface hydrophobicity, and membrane fusion. J. Membr. Biol. 1990, 114, 195-203. [CrossRef]

49. Tallarida, R.J. Drug Synergism and Dose-Effect Data Analysis; Chapman \& Hall: Boca Raton, FL, USA, 2000; 267p.

50. Chou, T.-C. Drug combination studies and their synergy quantification using the Chou-Talalay Method. Cancer Res. 2010, 70, 440-446. [CrossRef]

51. Andrews, J.M. Determination of minimum inhibitory concentrations. J. Antimic. Chemother. 2001, 48 (Suppl. S1), 5-16. [CrossRef]

52. MIC Clinical and Laboratory Standards Institute: M07-A9, Methods for Dilution Antimicrobial Susceptibility Tests for Bacteria that Grow Aerobically, 9th ed.; Approved Standard; CLSI: Wayne, PA, USA, 2012; ISBN 1-56238-784-7. Available online: www.clsi.org (accessed on 1 November 2021).

53. Gokel, G.W.; Barbour, L.J.; Ferdani, R.; Hu, J. Lariat ether receptor systems show experimental evidence for alkali metal cation-pi interactions. Acc. Chem. Res. 2002, 35, 878-886. [CrossRef]

54. Gokel, G.W. The aromatic sidechains of amino acids as neutral donor groups for alkali metal cations. Chem. Commun. 2003, 23, 2847-2852. [CrossRef] [PubMed] 